\title{
Pathway dissection, regulation, engineering and application: lessons learned from biobutanol production by solventogenic clostridia
}

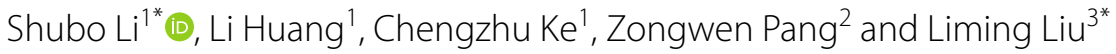

\begin{abstract}
The global energy crisis and limited supply of petroleum fuels have rekindled the interest in utilizing a sustainable biomass to produce biofuel. Butanol, an advanced biofuel, is a superior renewable resource as it has a high energy content and is less hygroscopic than other candidates. At present, the biobutanol route, employing acetone-butanolethanol (ABE) fermentation in Clostridium species, is not economically competitive due to the high cost of feedstocks, low butanol titer, and product inhibition. Based on an analysis of the physiological characteristics of solventogenic clostridia, current advances that enhance ABE fermentation from strain improvement to product separation were systematically reviewed, focusing on: (1) elucidating the metabolic pathway and regulation mechanism of butanol synthesis; (2) enhancing cellular performance and robustness through metabolic engineering, and (3) optimizing the process of ABE fermentation. Finally, perspectives on engineering and exploiting clostridia as cell factories to efficiently produce various chemicals and materials are also discussed.
\end{abstract}

Keywords: Acetone-butanol-ethanol fermentation, Solventogenic clostridia, Metabolic characteristics, Metabolic engineering, Strain improvement, Process optimization

\section{Background}

Due to the limited supply of petroleum oil, mounting environmental concerns, and an awareness of the energy crisis, it has become necessary to investigate a renewable biofuel as a substitute for oil [1, 2]. Butanol, a fourcarbon primary alcohol, is appealing commercially not only as an important bulk chemical, but also as a promising biofuel because of its superior characteristics [3-5]. However, commercial butanol is currently derived via a petrochemical route based on propylene oxo synthesis,

\footnotetext{
*Correspondence: shubo1207@gxu.edu.cn; mingll@jiangnan.edu.cn ${ }^{1}$ College of Light Industry and Food Engineering, Guangxi University, Nanning 530004, China

${ }^{3}$ State Key Laboratory of Food Science and Technology, Jiangnan University, Wuxi 214122, China

Full list of author information is available at the end of the article
}

which is extremely sensitive to the price of crude oil [3]. Therefore, as the most viable route of biobutanol production, the acetone-butanol-ethanol (ABE) fermentation using Clostridium species has been attracting increasing interest in both academia and industry [6,7], and several retrofitted and new industrial plants are under construction or even operating globally [8].

Once one of the largest fermentation industries, clostridia-based ABE fermentation [producing acetone, butanol, and ethanol at the ratio of 3:6:1 (mass ratio)] was first reported by Louis Pasteur in 1861, and developed to an industrial production level by Chaim Weizmann in 1912 [9]. Unfortunately, despite the substantial improvements that have been obtained over the past 100 years, several drawbacks still severely detract from the economic feasibility of $\mathrm{ABE}$ fermentation, including the: (1) high cost of substrate and substrate inhibition;

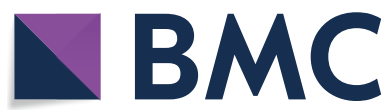

(c) The Author(s) 2020. This article is licensed under a Creative Commons Attribution 4.0 International License, which permits use, sharing, adaptation, distribution and reproduction in any medium or format, as long as you give appropriate credit to the original author(s) and the source, provide a link to the Creative Commons licence, and indicate if changes were made. The images or other third party material in this article are included in the article's Creative Commons licence, unless indicated otherwise in a credit line to the material. If material is not included in the article's Creative Commons licence and your intended use is not permitted by statutory regulation or exceeds the permitted use, you will need to obtain permission directly from the copyright holder. To view a copy of this licence, visit http://creativeco mmons.org/licenses/by/4.0/. The Creative Commons Public Domain Dedication waiver (http://creativecommons.org/publicdomain/ zero/1.0/) applies to the data made available in this article, unless otherwise stated in a credit line to the data. 


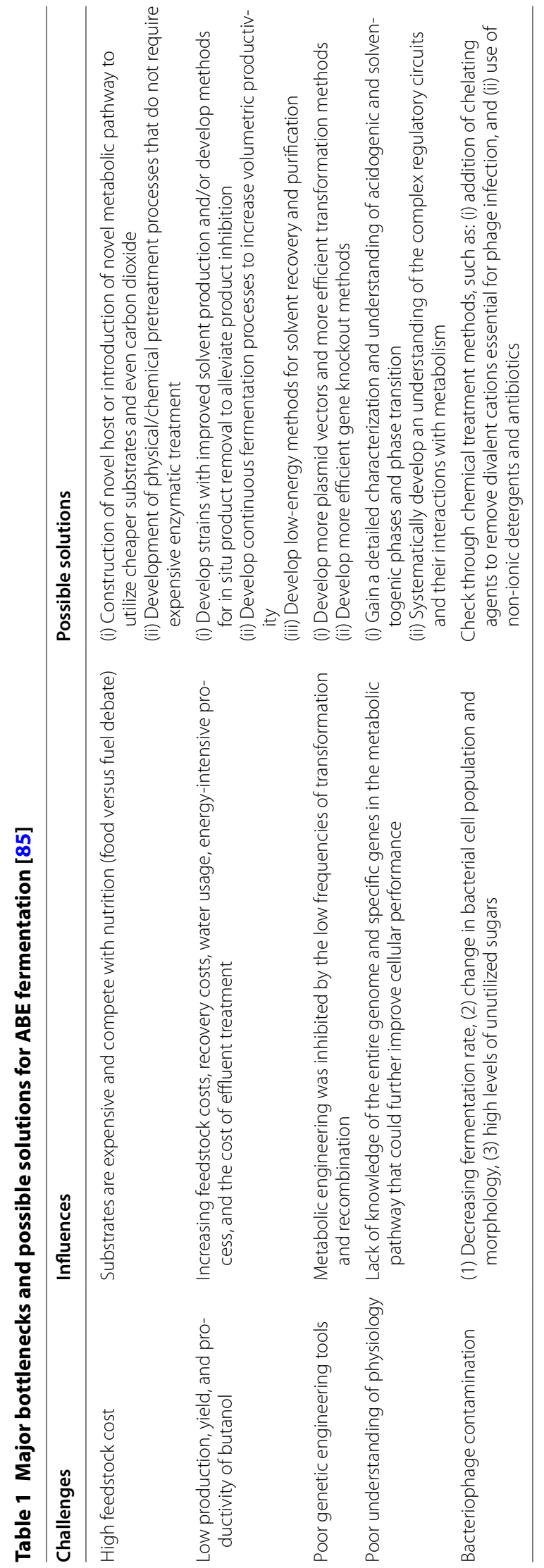


(2) sluggish growth and low cell density; (3) low butanol concentration $(<20 \mathrm{~g} / \mathrm{L})$, yield $(<0.33 \mathrm{~g} / \mathrm{g})$, and productivity $(<0.5 \mathrm{~g} / \mathrm{L} / \mathrm{h}) ;(4)$ undesirable butanol selectivity; (5) extra energy consumption for butanol purification; (6) few tools appropriate for genetic engineering, and (7) poor understanding of the physiological characteristics of clostridia $[1,10,11]$ (Table 1$)$.

To this end, substantial efforts have been expended to develop a superior hyper-butanol-producing strain to revive industrial ABE fermentation, including: (1) expanding the selection of low-cost feedstock; (2) improving the butanol titer and tolerance; (3) adopting continuous or repeated fed-batch fermentations, and (4) increasing butanol selectivity with efficient recovery techniques (Table 1) $[12,13]$. Meanwhile, to overcome the intrinsic weaknesses of clostridia, nonsolvent-producing species, such as Escherichia coli and Saccharomyces cerevisiae, have been engineered by synthetic biological means to produce butanol [14]. As a consequence, various review articles have been published recently that summarize the general aspects of $A B E$ fermentation [1] and focus on the metabolic pathways and metabolic engineering tools of clostridia $[15,16]$, redox potential regulation [17], economical substrate-derived carbohydrates [18-20], butanol toxicity and tolerance [21, 22], butanol fermentation technology [23], as well as butanol separation techniques [24-26]. Here, the intention of this review is to sum up the development of clostridia-based ABE fermentation from strain improvement to bioprocess optimization, particularly focusing on recent research progresses in dissecting metabolic pathway and relevant regulation mechanism of butanol production in solventogenic clostridia. Additionally, the derivative strategies that were used to engineer clostridia to improve cellular performance and fermentation process are also discussed, providing guidelines for enhancing the overall performance of $\mathrm{ABE}$ fermentation, and converting $\mathrm{ABE}$ to the production of higher value-added chemicals.

\section{Microorganisms and metabolic characteristics of ABE fermentation}

\section{Microorganisms for $A B E$ fermentation}

The strictly anaerobic genus Clostridium can select from at least 14 distinct families of glycosyl hydrolases, including $\alpha$-amylase, $\alpha$-glucosidase, $\beta$-amylase, $\beta$-glucosidase, glucoamylase, pullulanase, and amylopullulanase, to degrade carbohydrate polymers to economically produce biochemicals (such as butyrate, ethanol, butanol, and hydrogen) [27-29]. However, only four species, Clostridium acetobutylicum, Clostridium beijerinckii, Clostridium saccaroperbutylacetonicum, and Clostridium saccharoacetobutylicum, exhibit significant activity for synthesizing butanol under appropriate conditions [30,31], among which C. acetobutylicum is the model organism for $\mathrm{ABE}$ fermentation, while $C$. beijerinckii is considered a potential candidate for lignocellulosic biomass-based ABE fermentation [32,33].

As an alternative strategy, several well-characterized microorganisms (such as E. coli [34], S. cerevisiae [35], Pseudomonas putida [36], and Bacillus subtilis) could also be engineered to synthesize butanol, and have been attracting increasing interest of late. Compared with the native butanol-producing microbes, these well-characterized microorganisms have fast growth rates, wellcharacterized genetic backgrounds, and well-established genetic manipulation systems, and are associated with more economically viable large-scale production processes [37, 38]. More importantly, some engineered strains have a superior butanol yield and fewer byproducts than clostridia, and are thus excellent hosts for butanol production [39].

\section{Metabolic characteristics of ABE fermentation}

Typically, various clostridia have similar metabolic pathways for $A B E$ fermentation, which can be divided into three different growth phases (acidogenesis phase, solventogenesis phase, and sporogenesis phase) and produce three major kinds of products: (1) solvents (acetone, ethanol, and butanol); (2) organic acids (acetic acid and butyric acid), and (3) gases (carbon dioxide and hydrogen) $[40,41]$ (Fig. 1).

\section{Acidogenesis and solventogenesis phases}

During exponential growth, the acidogenesis phase commences and is accompanied by changes in the intracellular microenvironment due to the accumulation of acetate and butyrate. As a result, a surplus of adenosine triphosphate (ATP) is generated as much as possible under anaerobic conditions, but a balance between the formation and utilization of reducing equivalents [reduced/ oxidized nicotinamide adenine dinucleotide (phosphate) ratio $\left.\mathrm{NAD}(\mathrm{P}) \mathrm{H} / \mathrm{NAD}(\mathrm{P})^{+}\right]$is unconditionally required for non-respiratory metabolism [42].

At the final stage of the acidogenesis phase, the severely acidified environment $(\mathrm{pH} 4.5)$ and the higher levels of ATP and $\mathrm{NAD}(\mathrm{P}) \mathrm{H} / \mathrm{NAD}(\mathrm{P})^{+}$become the primary stress signals for activating the synthesis of solventogenic enzymes, shifting the metabolic activity rapidly from the acidogenesis phase to the solventogenesis phase [15, 43]. Subsequently, the activation of gene circuitry could be triggered by various environmental stresses, such as butyryl-phosphate [44], formic acid [45], and other environmental factors [46], which would then alter cellular activities to produce solvents [47]. As a consequence, acetate and butyrate are re-assimilated to generate 


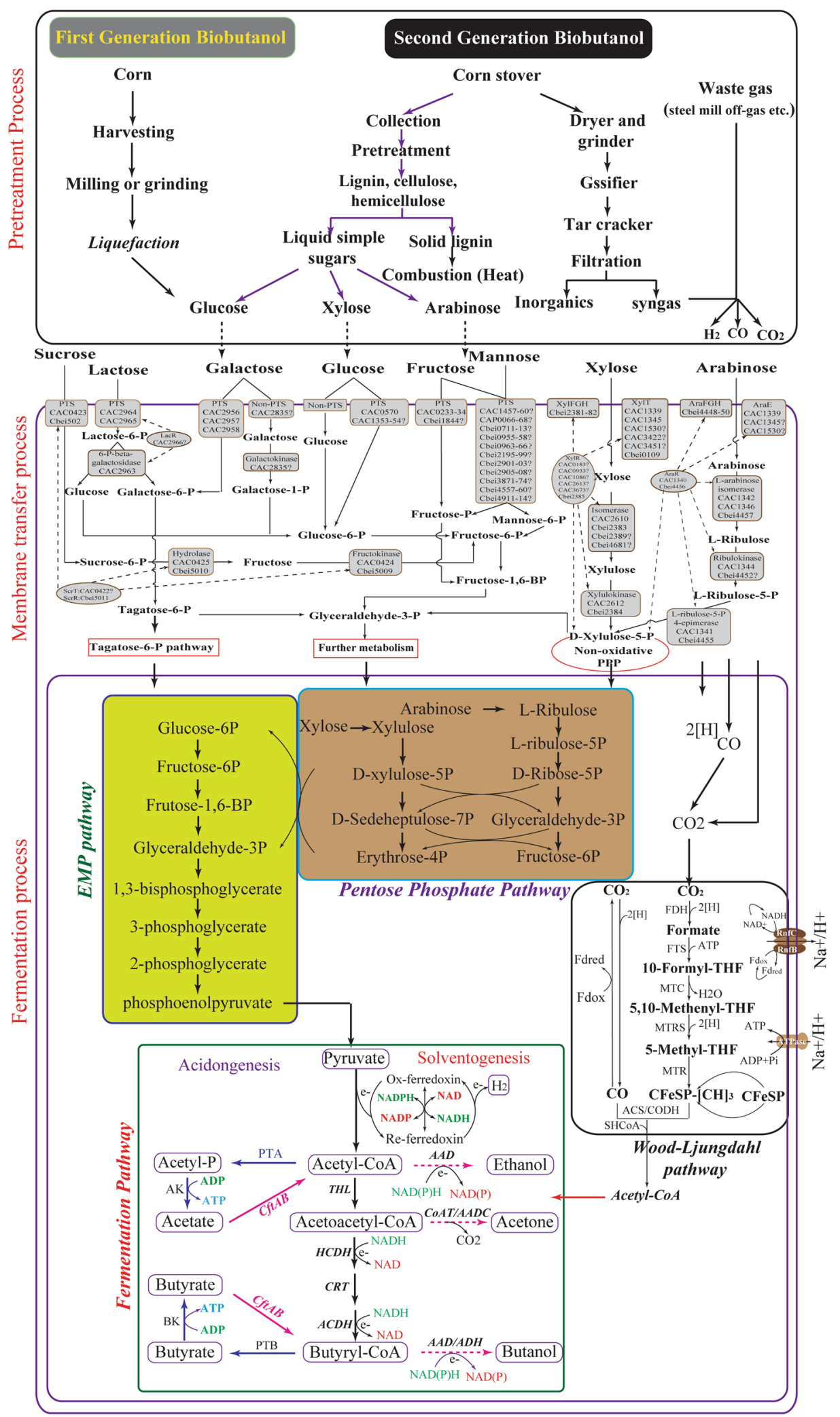




\begin{abstract}
(See figure on previous page.)
Fig. 1 Simplified metabolism of biomass for microbial n-butanol fermentation by solventogenic clostridia through pretreatment process, membrane transfer process and fermentation process, especially depiction of metabolic pathways, energy conservation and the related enzymes for butanol production, in which glycolysis, the pentose phosphate pathway, and the Wood-Ljungdahl pathway are necessary for growth on hexoses, pentoses, and syngas, respectively. Abbreviations of the different metabolites or enzymes are as follows: $A A D$ alcohol/aldehyde dehydrogenase, $A A D C$ acetoacetate decarboxylase, $A C D H$ acyl-CoA dehydrogenase, $A C S / C O D H$ acetyl-CoA synthase/CO dehydrogenase, $A D H$ alcohol dehydrogenase, AK acetate kinase, ALDC acetolactate decarboxylase, ALDH aldehyde dehydrogenase, BK butyrate kinase, CAT CoA transferase, CFeSP corrinoid iron-sulfur protein, CRT crotonase, Etf electron-transferring flavoprotein, Fd ferredoxin, FDH formate dehydrogenase, FTS formyl-THF synthase, MTC methenyl-THF cyclohydrolase, MTD methylene-THF dehydrogenase, MTR methyl transferase, MTRS methylene-THF reductase, PFK-1 phosphofructokinase, PFOR pyruvate:ferredoxin oxidoreductase, $P$ GK phosphoglycerate kinase, $P$ GM phosphoglycerate mutase, $P K$ pyruvate kinase, PTA phosphotransacetylase, PTB phosphotransbutyrylase, THL thiolase, TPI triosephosphate isomerase (adapted from [10, 29, 123])
\end{abstract}

coenzyme A (CoA) derivatives (acetyl-CoA and butyrylCoA), using acetoacetyl-CoA as the CoA donor, and ethanol and butanol are produced by different dehydrogenases under the limitation of reducing equivalents $[15$, 48] (Fig. 1).

\section{Sporogenesis phase}

After entering the stationary phase, the cells synthesize granulose as an intracellular storage compound, and then the sporulation process is initiated along with the cessation of solvent formation [49]. From the viewpoint of industrial applications, sporulation is an intrinsic drawback for clostridia, and a solvent-producing, non-sporulating strain may be more desirable for ABE fermentation, as avoiding sporulation without ceasing solvent formation would benefit specific cell productivity and simplify bioprocessing. However, the sporulation process is a carefully orchestrated cascade of events at both the transcriptional and posttranslational levels involving a multitude of sigma factors, transcription factors, proteases, and phosphatases, making the regulation mechanism of the sporulation process still incompletely understood at the molecular level [50,51]. As for solventogenic clostridia, sequenced Clostridium genomes contain genes for all major sporulation-specific transcription and sigma factors (spoOA, sigH, sigF, sigE, sigG, and sigK) that orchestrate the sporulation program [52, 53]. More importantly, it is unclear how sporulation-specific sigma factors affect solvent formation [54], and even some asporogenous mutants are unable to synthesize solvents [7]. For example, inactivation of $\sigma^{F}$ in C. acetobutylicum could effectively block sporulation prior to asymmetric division, but had no effect on solvent formation [54]. However, unlike the $\sigma^{F}$ and $\sigma^{E}$ inactivation strains, the SpoIIE inactivation strain did not exhibit inoculumdependent solvent formation and produced good levels of solvents from both exponential- and stationary-phase inoculation [55]. At present, there are three strategies that could be used to construct asporogenous strains: random mutagenesis, engineering specific sporulation stages, and starting with asporogenous, non-solventogenic strains (such as M5 and DG1) [56].

\section{Central metabolic pathway for butanol synthesis}

With the publication of genomic data for several solventogenic clostridia, such as C. saccharobutylicum NCP262 [57], C. beijerinckii [58], C. acetobutylicum ATCC 824 [59-61], C. acetobutylicum DSM 1731 [62], and C. acetobutylicum EA2018 [63], the metabolic pathway for butanol production has been comprehensively elucidated and is mediated by CoA (Fig. 1) [64, 65].

\section{Carbon metabolism}

In brief, clostridia species can uptake a wide range of hexoses, pentoses, and oligomers through the phosphoenolpyruvate-dependent phosphotransferase system (PTS) and/or non-PTS transport systems [66, 67]. Subsequently, hexoses and pentoses [first via the pentose phosphate pathway (PPP)] are degraded to pyruvate through the Embden-Meyerhof-Parnas (EMP) pathway along with the production of ATP and NADH $[68,69]$. Finally, the key intermediates of acetyl-CoA and butyryl-CoA are converted into oxidized products (i.e., acetone, acetate, or $\mathrm{CO}_{2}$ ) or reduced products (i.e., butanol, ethanol, or butyrate) via six key enzymes (thiolase, 3-hydroxybutyryl-CoA dehydrogenase, crotonase, butyryl-CoA dehydrogenase, butyraldehyde dehydrogenase, and butanol dehydrogenase) [70] (Fig. 1). Theoretically, $1 \mathrm{~mol}$ of glucose can be converted into $1 \mathrm{~mol}$ of butanol $(0.41 \mathrm{~g} / \mathrm{g})$, $1 \mathrm{~mol}$ of acetone $(0.32 \mathrm{~g} / \mathrm{g})$, or $2 \mathrm{~mol}$ of ethanol $(0.51 \mathrm{~g} / \mathrm{g})$, but the actual $A B E$ yield is significantly decreased due to the production of biomass, the non-assimilation of acetic acid and butyric acid, and the formation of other carbohydrates.

\section{Redox metabolism}

As shown in Fig. 1, synthesizing $1 \mathrm{~mol}$ of butanol consumes $4 \mathrm{~mol}$ of $\mathrm{NADH}$, but the reduction in NADH level occurs during the phase transition, suggesting that a high $\mathrm{NADH} / \mathrm{NAD}^{+}$ratio benefits redistribution of the metabolic flux and solvent production [71, 72]. Therefore, increasing the intracellular NADH level (e.g., by up-regulating the NADH formation pathway or downregulating the $\mathrm{NADH}$ consumption pathway) contributes to enhanced butanol formation [73]. In clostridia, three 
metabolic pathways regulate intracellular NADH/electron flow: (1) NADH-ferredoxin reductase and hydrogenase [74]; (2) Bcd/EtfAB complex and hydrogenase [75], and (3) bifurcating hydrogenase oxidizing NADH and ferredoxin simultaneously [76]. Recently, with the elucidation of the crystal structure of $C$. acetobutylicum thiolase (CaTHL) in reduced/oxidized states, CaTHL could be mediated by the redox-switch modulation through reversible disulfide bond formation between two catalytic cysteine residues, Cys88 and Cys378, and then affected overall metabolic flux distribution and the acidogenic to solventogenic phase transition, providing metabolic engineering and fermentation strategies for enhancing butanol production [77].

\section{Energy metabolism}

Similar to the dosage effect of NADH, high ATP levels not only effectively drive carbon flux towards butanol by blocking butyrate synthesis, but also improve cellular performance by alleviating butanol toxicity $[78,79]$. However, the formation of butanol effectively inhibits ATP generation, and then down-regulates the expression of pyruvate kinases and phosphoglycerate kinase [80]. Considering both carbon and redox balances, $2 \mathrm{~mol}$ of ATP are produced by glycolysis and the reducing equivalents can be regenerated in the butanol pathway, and then the reduced ferredoxin transfers its electrons to $\operatorname{NAD}(\mathrm{P})^{+}$ with no molecular hydrogen formed. Therefore, artificially increasing the ATP accumulation (e.g., by inactivating the acetate and butyrate pathways) could improve the production and selectivity of butanol, but the energy distribution has become the challenge $[14,81]$. More importantly, energy conservation in anaerobic bacteria is quite difficult and almost nothing is known about the genetic regulation of energy and redox status in clostridia.

Thus far, although the solvent-producing pathway has been comprehensively elucidated, differentiation of clostridia (i.e., sporulation) is still poorly understood. In particular, the regulatory mechanism of granulose formation and reutilization, the regulatory mechanism underlying the transition between acidogenesis and solventogenesis, and the molecular regulatory switches between sensing and transferring redox signals are still unknown $[1,82]$.

\section{Improvement in cellular performance for ABE fermentation}

For $\mathrm{ABE}$ fermentation the biggest challenge is the low butanol yield due to the significant production of byproducts and butanol toxicity. To this end, several phenotypic traits (such as solvent tolerance, aerotolerance [83], or abolished sporulation [84]) were chosen as important selective principles underlying the development of robust strains with superior metabolic capabilities [85] (Fig. 2).

\section{Strain improvement by mutation}

During the pre-genomic era, mutagenesis of clostridia through physical or chemical methods was routinely and successfully executed to obtain the desired phenotypes (Table 2). For example, combining with the

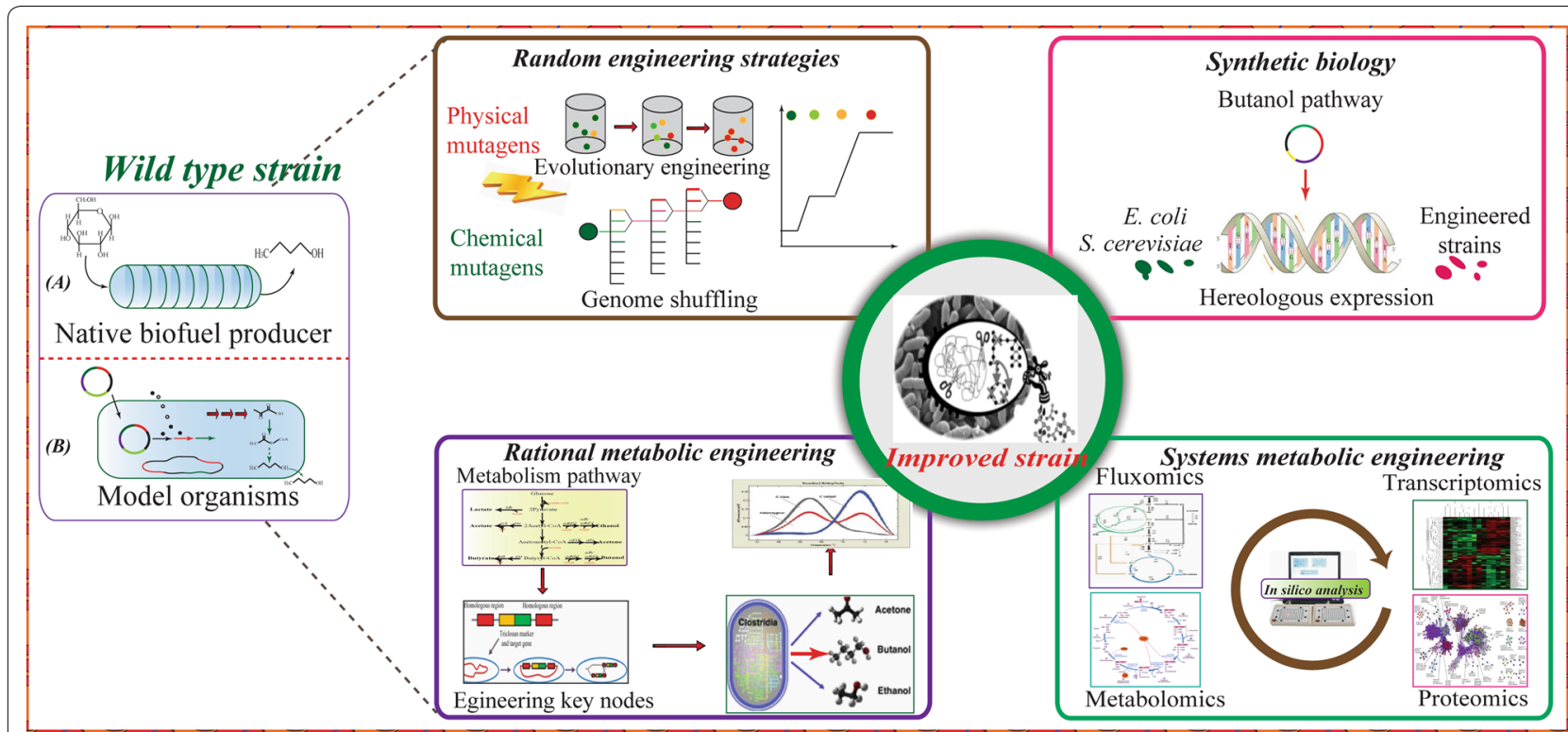

Fig. 2 Strategies for improving cellular characteristics though random engineering, rational metabolic engineering, systems metabolic engineering, and synthetic biology (adapted from [222]) 
Table 2 Application of various strategies to improve cellular performance for ABE fermentation

\begin{tabular}{|c|c|c|c|}
\hline Strain & Strategy ${ }^{a}$ & $\begin{array}{l}\text { Physiological characteristics (control/engineered } \\
\text { strain) }\end{array}$ & Refs. \\
\hline \multicolumn{4}{|l|}{ Mutagenesis strategies } \\
\hline C. acetobutylicum BKM19 & $\begin{array}{l}\text { Random mutagenesis, screening cells on fluoroacetate } \\
\text { plates }\end{array}$ & $\begin{array}{l}\text { Butanol: } 15.9 / 17.6 \mathrm{~g} / \mathrm{L} \\
\text { Total solvent: } 24.9 / 32.5 \mathrm{~g} / \mathrm{L}\end{array}$ & [195] \\
\hline C. acetobutylicum JB200 & Evolution in a fibrous bed bioreactor & $\begin{array}{l}\text { Butanol: } 12.6 / 21.0 \mathrm{~g} / \mathrm{L} \\
\text { Total solvents: } 19.4 / 32.6 \mathrm{~g} / \mathrm{L}\end{array}$ & {$[93]$} \\
\hline C. acetobutylicum GX01 & NTG, genome shuffling and butanol exposure & $\begin{array}{l}\text { Butanol: } 16.3 / 20.1 \mathrm{~g} / \mathrm{L} \\
\text { Total solvents: } 26.4 / 32.6 \mathrm{~g} / \mathrm{L}\end{array}$ & {$[86]$} \\
\hline \multicolumn{4}{|l|}{ Metabolic engineering strategies } \\
\hline \multicolumn{4}{|l|}{ Enhancing butanol production } \\
\hline C. acetobutylicum ATCC 824 & Overexpressing both $p f k A$ and $p y k A$ genes & $\begin{array}{l}\text { Butanol: } 14.78 / 19.12 \mathrm{~g} / \mathrm{L} \\
\text { Total solvents: } 21.76 / 28.02 \mathrm{~g} / \mathrm{L}\end{array}$ & {$[78]$} \\
\hline C. acetobutylicum JB200 & Disrupting the cac3319 gene & Butanol: 12.6/18.2 g/L & [93] \\
\hline C. beijerinckii CC101 & Overexpressing adhE2 and ctfAB & Butanol: 2.6/12.0 g/L & [223] \\
\hline \multicolumn{4}{|l|}{ Increasing butanol selectivity } \\
\hline C. acetobutylicum ATCC 824 & Knocking out solR & $\begin{array}{l}\text { Butanol: } 5.48 / 17.79 \mathrm{~g} / \mathrm{L} \\
\text { Butanol ratio: } 55 \% / 66 \%\end{array}$ & [224] \\
\hline C. acetobutylicum EA 2018 & $\begin{array}{l}\text { Disrupting the acetone pathway by TargeTron technol- } \\
\text { ogy }\end{array}$ & $\begin{array}{l}\text { Butanol: } 7.4 / 13.6 \mathrm{~g} / \mathrm{L} \\
\text { Butanol ratio: } 71 / 82 \%\end{array}$ & {$[43]$} \\
\hline \multicolumn{4}{|l|}{ Improving butanol tolerance } \\
\hline C. acetobutylicum & Overexpressing HSP genes grpE and $h t p G$ & $\begin{array}{l}\text { Improved butanol tolerance with increases of 25\% } \\
\text { (grpE) and } 56 \%(h t p G)\end{array}$ & [167] \\
\hline C. acetobutylicum & Overexpressing gsh $A B$ genes from $E$. coli & $\begin{array}{l}\text { Increased cell resistance against butanol stress (from } \\
14.5 \text { to } 18 \mathrm{~g} / \mathrm{L} \text { ), and aero-stress }\end{array}$ & {$[83]$} \\
\hline
\end{tabular}

${ }^{a} N T G N$-methyl- $N$-nitro- $N$-nitrosoguanidine

selective enrichment of glucose analogue 2-deoxyglucose and $N$-methyl- $N$-nitro- $N$-nitrosoguanidine (NTG) mutagenesis, a super butanol producing strain C. beijerinckii BA101 was obtained that significantly increased the butanol and total solvent yield from $9 \mathrm{~g} / \mathrm{L}$ and $13 \mathrm{~g} / \mathrm{L}$ to $19 \mathrm{~g} / \mathrm{L}$ and $29 \mathrm{~g} / \mathrm{L}$, respectively [2]. Similarly, through butanol resistance screening and NTG mutagenesis, $C$. acetobutylicum EA2018 was also successfully isolated with a higher acetone-butanol-ethanol ratio of 2:7:1 (mass ratio) [63]. Furthermore, with a combination of chemical mutagenesis, genome shuffling, and butanol exposure, the mutant produced $20.1 \mathrm{~g} / \mathrm{L}$ of butanol at $0.35 \mathrm{~g} / \mathrm{L} / \mathrm{h}$, which were, respectively, $23.3 \%$ and $40.0 \%$ higher than the parent strain [86]. However, although traditional random mutagenesis combined with the screening method was still the most successful strategy for developing a high butanol-producing strain, it was difficult to further improve the physiological properties of the mutant due to the unknown and complex genotypic/ phenotypic changes associated with identifying the modified genes [87].

\section{Strain improvement by metabolic engineering}

To address the drawbacks of mutagenesis in theory, various omics technologies (transcriptomics, proteomics, and metabolomics) have been applied to systematically elucidate the complex genotypic/phenotypic changes at different levels [88], providing an amount of targeted genes or proteins that further improve cellular performance by considering the metabolic pathway in its entirety [89].

\section{Engineering tools for clostridia}

Compared to well-characterized microorganisms, Clostridium is notorious for the difficulty of genetic manipulations, and consequently only a few genetic tools can be used for engineering clostridia. With respect to gene cloning, much progress involving shuttle vectors, transformation and conjugation, circumvention of restriction barriers, and transposon mutagenesis, has been made in heterologous expression in clostridia [90] (Table 3). However, due to the low frequencies of transformation and recombination, as well as the double crossover integration, only three types of vectors, non-replicative and replicative integrative plasmids, a group II intron-based TargeTron technology and ACE (allele-coupled exchange) vector, have been developed for gene inactivation in clostridia [61, 91, 92]. Fortunately, the clustered regularly interspaced short palindromic repeats (CRISPR)/CRISPR-associated protein 9 


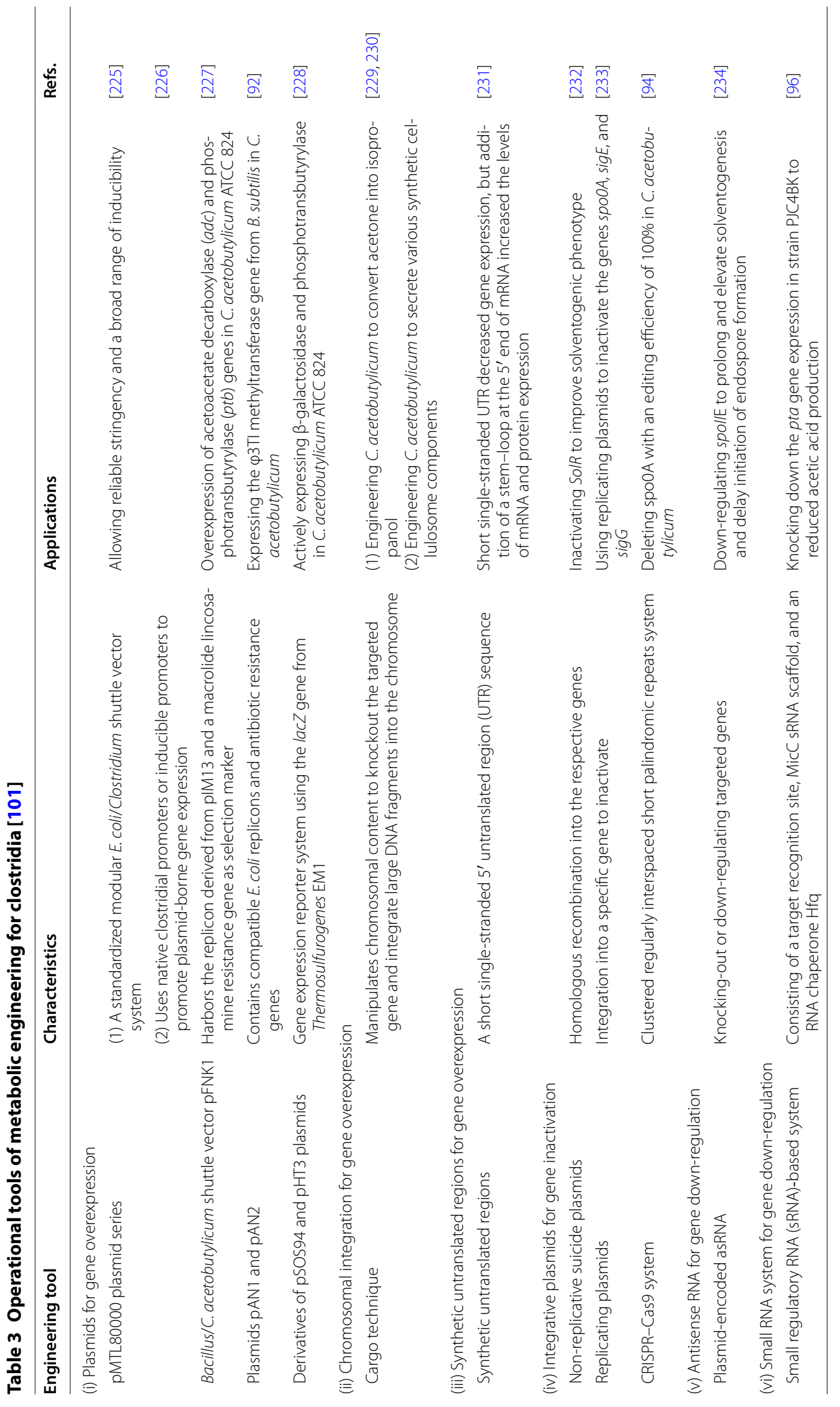




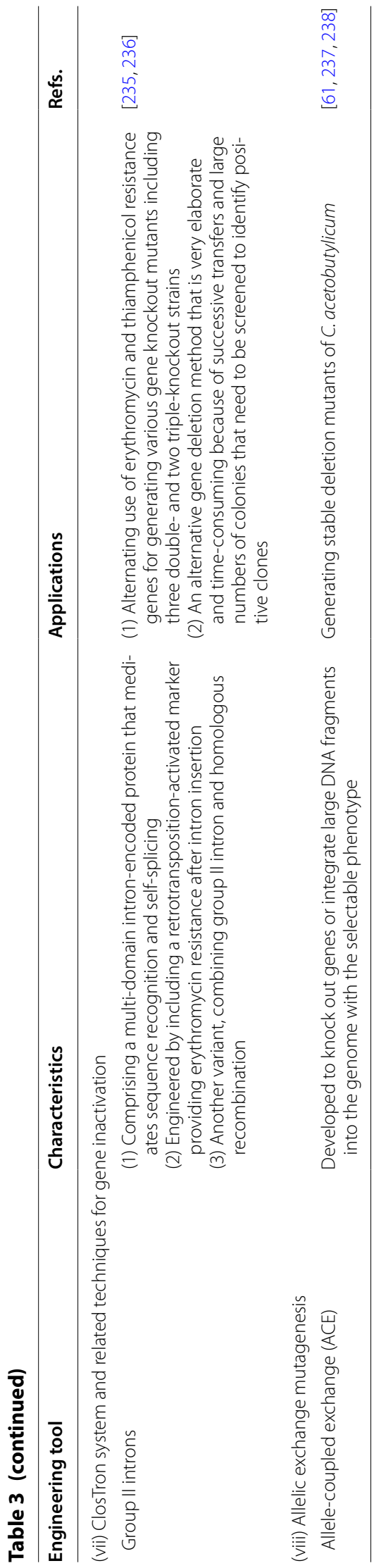


(Cas9) system has been successfully applied to edit the genomes of C. cellulolyticum [93], C. acetobutylicum [4], C. tyrobutyricum [94], and C. beijerinckii [95], achieving multiple genome-engineered mutants. Furthermore, a synthetic small regulatory RNA (sRNA)-based system, consisting of a target recognition site, MicC sRNA scaffold, and an RNA chaperone Hfq, was also developed to control or knock down gene expression for C. acetobutylicum with stability and efficiency [96]. More importantly, with the combination of high-throughput technologies, large amounts of omics data, and advances in computational biology, several genome-scale metabolic models (GSMMs) were constructed for clostridia [97, 98], providing the vital platform for visualizing the metabolic changes at a global level and predicting cellular phenotypes from genotype [99, 100] (Fig. 3).

\section{Strain improvement by metabolic engineering}

Enhancement of solvent production At present, two strategies, regulating genes associated with solvent formation and altering the metabolic regulatory system, have been developed to further enhance solvent production in clostridia [101]. First, to directly reinforce the butanol biosynthesis pathway, four genes ( $p t a, a c k, p t b$, and $b u k$ ) involved in short-chain fatty acid synthesis were individually or combinatorially knocked out in C. acetobutylicum ATCC 824, resulting in a higher titer $(16 \mathrm{~g} / \mathrm{L})$ of butanol being produced in the pta/buk double-knockout mutant. Meanwhile, with the integration of an overexpressing variant $a d h E 1$ gene, the production of butanol was further increased to $18.9 \mathrm{~g} / \mathrm{L}$ [102].

Additionally, regulatory proteins, affecting a larger set of pathways, programs, or signal transduction, could also be engineered to achieve desirable phenotypes. As a transcriptional regulator, SolR can positively control sporulation and solvent production, so that the combination of inactivating SolR and overexpressing aad was used to improve cellular performance, increasing the production of butanol, acetone, and ethanol to $17.6 \mathrm{~g} / \mathrm{L}, 8.2 \mathrm{~g} / \mathrm{L}$, and $2.2 \mathrm{~g} / \mathrm{L}$, respectively [103]. More importantly, other regulatory factors (such as SpoIIE, sigF, sigE, and sigG) have been identified as being involved with improving cell growth and solvent formation, showing that understanding the regulatory mechanism of the solventogenic shift is of great interest, but identification of the molecular triggering machinery still presents an obstacle [104].

Improvement of butanol selectivity Acetone, the major by-product representing $30 \%$ of the total mass, is considered the most undesirable product due to its poor fuel properties [105], and therefore inhibiting acetone production by developing a high butanol proportion or butanolonly strain could effectively improve the economics of
$\mathrm{ABE}$ fermentation $[43,106]$. But interestingly, disrupting acetoacetate decarboxylase (encoding by $a d c$ ) effectively inhibits acetone production, increasing the butanol mass ratio from 70 to $80 \%$, but significantly decreases the butanol production from 13.6 to $7.4 \mathrm{~g} / \mathrm{L}$ [43]. Therefore, eliminating or reducing the acetone flux was not sufficient to increase butanol production, and even decreased butanol production due to an increase in the accumulation of acid [43]. In addition, engineering aldehyde/alcohol dehydrogenase (AAD) was also used to enhance butanol selectivity in $C$. acetobutylicum, dramatically increasing the butanol/ethanol ratios (B/E ratios) to 17.47 and $15.91 \mathrm{~g}$ butanol/g ethanol for $\mathrm{AAD}_{\mathrm{F} 716 \mathrm{~L}}$ and $\mathrm{AAD}_{\mathrm{N} 655 \mathrm{H}}$, respectively, which were 5.8- and 5.3-fold higher than the wild-type AAD [107].

Recently, real progress in raising the butanol ratio was achieved using strains M5 and DG1 (mutants without megaplasmid pSOL1). As shown in Table 2, when both adhE1 and ctfAB were co-expressed in M5, the mutant could produce $11.4 \mathrm{~g} / \mathrm{L}$ of butanol with a butanol mass ratio of 0.84 [106]. Apart from M5 and DG1, a novel advance involving disrupting the $a d c$ gene was developed, in which the production of acetone decreased from 2.83 to $0.21 \mathrm{~g} / \mathrm{L}$ but the production of butanol was still $12-13 \mathrm{~g} / \mathrm{L}$, through $\mathrm{pH}$-controlled fermentation and the addition of methyl viologen, so that the butanol mass ratio increased to over $82 \%$ [43]. However, because of the relatively poor understanding of solventogenic clostridia, great challenges still remain in realizing a real butanolonly process through metabolic engineering, such as how to block branch pathways without generating undesired phenotypes (e.g., acids assimilation, deficient growth rate), how to drive the carbon flow specifically to butanol, and how to provide sufficient reducing force to support butanol formation $[27,108]$.

Improvement of carbohydrate utilization As reported in the literature, substrate costs, which constitute approximately $60 \%$ of the total process cost [1], are the most important factor affecting the economic feasibility of $\mathrm{ABE}$ fermentation. Therefore, exploring low-cost substrates (such as energy-dense lignocellulosic biomass [13, 18, 109], oleaginous microalgae [110], and greenhouse gases [111]) is essential to improve the economic feasibility of $\mathrm{ABE}$ fermentation.

As the most abundant form of carbohydrate, lignocellulosic biomass (including forest residues, agricultural residues, and energy crops) is one of the best solutions for sustainable development of ABE fermentation [112]. However, clostridia cannot directly utilize cellulose or lignocellulosic biomass as a carbon source for butanol production [112]. Therefore, ABE fermentation from lignocellulosic materials needs to be improved through 


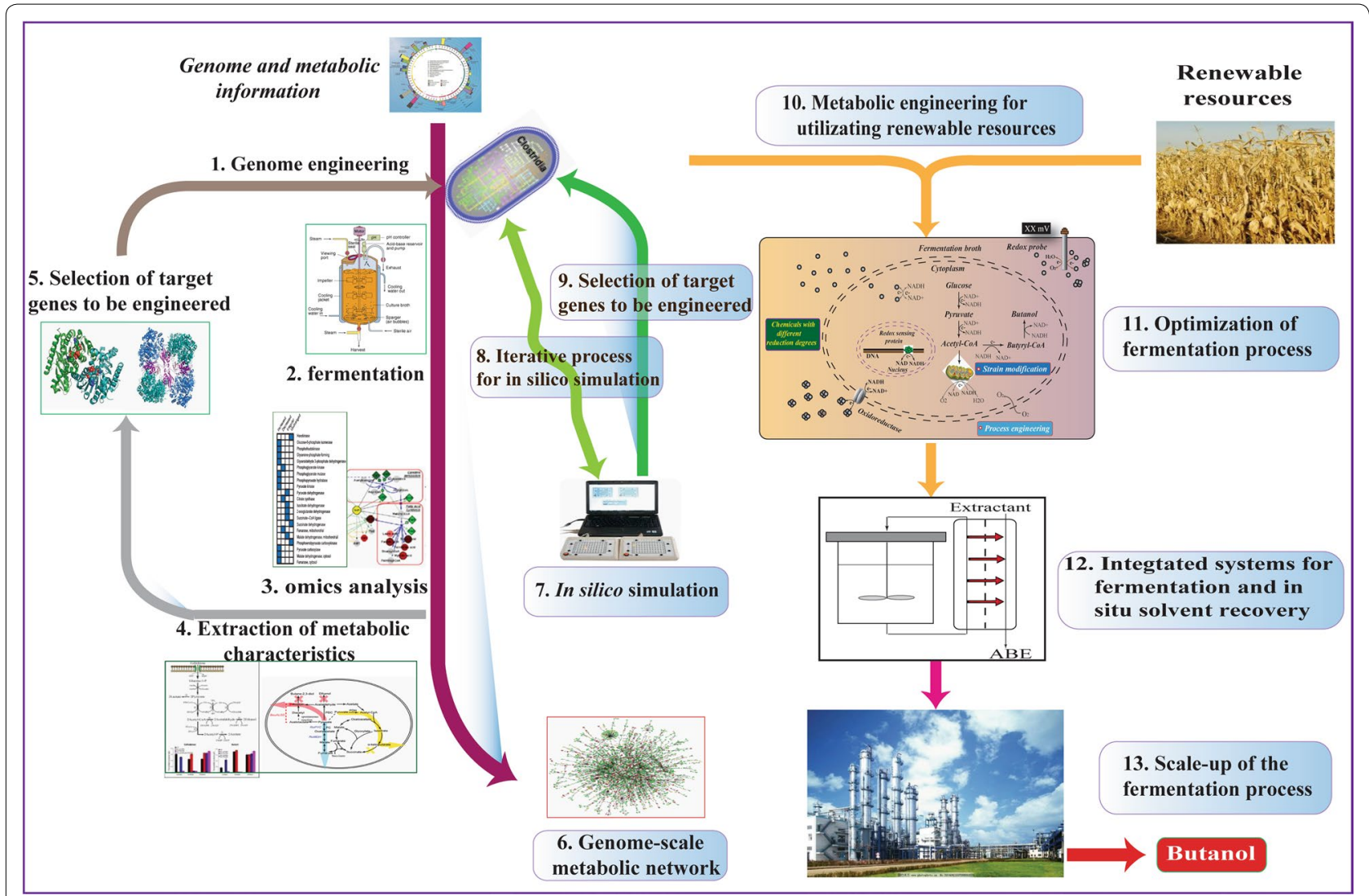

Fig. 3 Strategies for developing an integrative bioprocess based on systems metabolic engineering for ABE fermentation (adapted from [203])

metabolic engineering of clostridia (overexpressing the heterologous minicellulosomes $[113,114])$ and/or pretreatment techniques. As for cellulosic ABE fermentation, it could be summarized as involving: (1) material pretreatment (reviewed elsewhere in detail [115]); (2) enzymatic hydrolysis of cellulose to monosaccharides (hexose and pentose); (3) sugar fermentation to butanol, and (4) product recovery by distillation [116]. However, the efficiency of the concurrent uptake and metabolism of hexose and pentose is significantly impeded by glucose-mediated carbon catabolite repression [29, 117]. To this end, some strategies have been developed to simultaneously utilize mixed sugars in clostridia, as follows: (1) engineering specific membrane-bound transport systems [118], such as deletion of xylose repressor (e.g., CcpA) [82] or overexpression of xylose transporter [119, 120]; (2) constructing a xylose pathway [121]; and (3) improving a cellular tolerance towards inhibitors contained in lignocellulosic hydrolysates [119, 122, 123]. For example, after alkali pretreatment and enzymatic hydrolysis, C. acetobutylicum can produce $14.17 \mathrm{~g} / \mathrm{L}$ of butanol with a yield of $0.22 \mathrm{~g} / \mathrm{g}$ sugars in a fed-batch fermentation from sugarcane bagasse [124]. However, the high cost of pretreatment processing has become the key factor for the economic feasibility of cellulosic $\mathrm{ABE}$ fermentation [10].

Recently, consolidated bioprocessing (CBP) has attracted increasing attention because it can accomplish hydrolytic enzymes production, lignocellulose degradation and microbial fermentation in one single step. Therefore, metabolic construction, isolation of novel cellulolytic/hemicellulolytic and solventogenic bacteria, or construction of microbial co-cultures to achieve direct butanol production from lignocellulose offers a promising alternative [125]. For example, with the expression of indigenous xylanase, Clostridium sp. strain NJP7 could produce $2.06 \mathrm{~g} / \mathrm{L}$ of butanol and $0.54 \mathrm{~g} / \mathrm{L}$ of isopropanol from hemicellulose through the simultaneous saccharification and fermentation via consolidated bioprocessing [126]. Furthermore, a newly isolated Thermoanaerobacterium sp. M5 could directly produce butanol (1.17 g/L) from xylan through $\mathrm{CBP}$ at $55{ }^{\circ} \mathrm{C}$. More importantly, with the establishment of co-cultivation system consisting of Thermoanaerobacterium sp. M5 and C. acetobutylicum NJ4, it could effectively enhance the butanol titer to $8.34 \mathrm{~g} / \mathrm{L}$ from xylan through CBP [127]. However, the 
CBP technology is still in its infant stage, and microorganisms, microbial consortia and/or condition at industrial scale should be further improved to achieve a high-yield and low-cost CBP process [128, 129].

To thoroughly resolve the debate between food vs. fuel, algal biomass and synthesis gas (syngas) were also investigated for butanol production [130, 131], and have become increasingly attractive in both academic and industrial circles (reviewed elsewhere in detail [10]). After the enzymatic hydrolysis, $C$. beijerinckii could produce a higher butanol production $(7.16 \mathrm{~g} / \mathrm{L})$ and yield (0.42 $\mathrm{g} / \mathrm{g}$ consumed substrates) with butanol selectivity ( 0.85 of mass ratio) from brown seaweed [132]. More interestingly, with the overexpression of $a d h E 2$ and fnr, C. carboxidivorans could produce $\sim 18 \%$ more butanol $(0.35 \mathrm{~g} / \mathrm{L})$ and $\sim 22 \%$ more ethanol $(2.44 \mathrm{~g} / \mathrm{L})$ than the wild type in the syngas fermentation [133].

\section{Strain improvement by enzyme engineering}

To date, most of the work to improve $\mathrm{ABE}$ fermentation has focused on increasing the quantity of enzymes involved in butanol biosynthesis, but significant progress has not been obtained. To this end, modifying enzymes with higher activities and specificities by enzyme engineering was developed as an alternative strategy [134, 135]. For butanol biosynthesis, most of the key enzymes have been purified and biochemically characterized (reviewed in detail elsewhere [15]), but only a few studies on engineering enzymatic properties were reported to improve $\mathrm{ABE}$ fermentation. For example, when the cofactor specificity of AdhE1 was attenuated by a simple D-485-G amino acid substitution, both NADPH and NADH could be used as electron donors, and subsequently, the AdhE1 activity was enhanced to further improve the carbon flux from acetyl-CoA to butanol via butyryl-CoA [102]. Furthermore, the thiolase of $C$. acetobutylicum was specifically engineered to reduce sensitivity towards coenzyme A (CoA-SH), significantly alleviating feedback inhibition through three amino acid substitutions (R133G, H156N, G222V) and, correspondingly, increasing the production of ethanol and butanol by $46 \%$ and $18 \%$, respectively, although acetone production was similar to the vector control strain [136]. More importantly, compared to the wide-type C. acetobutylicum thiolase (CaTHL), the CaTHL ${ }^{\mathrm{V} 77 \mathrm{Q} / \mathrm{N} 153 \mathrm{Y} / \mathrm{A} 286 \mathrm{~K}}$ mutant exhibited higher activity with more than threefold. As a result, when the $t h l_{C a}^{\mathrm{V} 77 \mathrm{Q} / \mathrm{N} 153 \mathrm{Y} / \mathrm{A} 286 \mathrm{~K}}$ gene was overexpressed in the thlA-knockdown mutant, the production of butanol was increased to $7.4 \mathrm{~g} / \mathrm{L}$, which was higher than that $(4.5 \mathrm{~g} / \mathrm{L})$ obtained with the thlA-knockdown mutant complemented with the $t h l_{\mathrm{Ca}}$ [77].

In summary, due to difficulties in genetic manipulation and complex physiology, a comprehensive understanding of the genes, pathways, and metabolic and regulatory characteristics is still lacking, and only limited metabolic engineering strategies have been successful in improving clostridia, so that traditional random mutagenesis is still the most successful method [25]. Therefore, the combination of metabolic engineering and evolutionary engineering was applied to further improve the overall performance of $\mathrm{ABE}$ fermentation. For example, with the integration of the overexpression of $a d h E 1$ and $c t f A-$ $c t f B-a d c$ and adaptive laboratory evolution approach, butanol production in the engineered $C$. cellulovorans increased from less than $0.025 \mathrm{~g} / \mathrm{L}$ to $3.47 \mathrm{~g} / \mathrm{L}$ in consolidated bioprocessing with deshelled corn cobs [137].

\section{Improvement of cellular robustness for ABE fermentation \\ Confronting different environmental stresses}

During $A B E$ fermentation, cell growth and butanol production can be significantly influenced by several inhibitory factors (such as product inhibition, substrate inhibition, dead cells, low water activity, nutrient deficiency, and $\mathrm{O}_{2}$ stress) [138], which could typically be classified as [139] acid stress, solvent stress, or synergistic multiple stresses.

\section{Acid stress}

Generally, solvent production through the re-assimilation of acetate and butyrate is a stress response to the acid inhibition of cells [140]. However, when the accumulation of acids is at a high level, the acidification of the cytoplasm or anion accumulation can dramatically inhibit cell growth and solvent production [141]. Therefore, improving cellular tolerance towards carboxylic acids (acetate and butyrate) could prolong cell growth to achieve a higher cell density and result in synthesis of more acids during the acidogenic stage [142, 143], and then increase butanol production at the solventogenic phase [144].

Furthermore, as for the cellulosic $\mathrm{ABE}$ fermentation, a number of associated compounds, such as salts, weak acids (i.e., acetic, formic, and levulinic), furan derivatives [i.e., hydroxymethylfurfural (HMF) and furfural], and phenolic compounds (i.e., $\rho$-coumaric acid, ferulic acid, hydroxybenzoic acid, vanillic acid, and syringaldehyde), were uncontrollably generated along with the pretreatment and hydrolysis processes of lignocellulosic biomass $[145,146]$. More importantly, the inhibitory effect of these compounds could be strengthened together due to a synergistic effect, and then severely affect microbial fermentation by low levels of ferulic acids and phenolic compounds $[3,147,148]$. 


\section{Solvent stress}

Due to its lipophilicity, butanol is in general extremely toxic for microorganisms, but much less is known about the specific impacts of solvents on clostridia [149]. When clostridia are exposed to butanol, adverse changes in phospholipid and fatty acid compositions of the cell membrane are induced, and then the unsaturated-tosaturated fatty acids ratio (U/S) decreases and the specific interactions of lipids are diminished [150]. More importantly, once butanol (a noxious organic solvent) enters the cytoplasmic membrane, it short-circuits the bilayer and creates a coupled system where interdigitated and splayed phospholipids coexist. Thus, it significantly impacts the physicochemical characteristics of the cell membrane, including preferential solute transport, glucose uptake, membrane permeability, maintenance of the proton motive force, the intracellular ATP level, and the activities of intrinsic membrane proteins $[139,151]$.

\section{Synergistic effect of multiple stresses}

The synergistic effect involves two aspects: relatively constant concentrations of toxic metabolites under chemostatically or well-controlled fed-batch fermentation and time course concentration changes in the toxic metabolites or concentration gradients developed under batch fermentation [152]. Therefore, effects created by supplementing fermentations with different levels of acetate, butyrate, and butanol individually were significantly different from those that occur during ABE fermentation, making the experimental results less meaningful [139]. As a result, the highest butanol titer produced by clostridia reported in laboratory research was $\sim 20 \mathrm{~g} / \mathrm{L}$ (the maximum tolerance of $C$. beijerinckii was $1.96 \%$ ) $[153,154]$, whereas only $\sim 12 \mathrm{~g} / \mathrm{L}$ butanol was produced under industrial conditions due to multiple, even simultaneous stresses [3].

In general, developing a strain with high butanol tolerance is the prerequisite for biobutanol production but, apparently, engineering strains with stress tolerance is more complicated than altering the butanol ratio and butanol production by metabolic engineering [22, 155, 156].

\section{Improvement of cellular robustness during $A B E$ fermentation}

During the long evolutionary process, microorganisms automatically develop a series of strategies to improve cellular robustness against environmental stresses (Fig. 4), including: (1) metabolic detoxification; (2) heat shock stress proteins (HSP); (3) the proton motive force and associated energy production; (4) molecular efflux pumps; (5) changes in cell membrane composition and biophysics, and (6) other transcriptional responses [22,
157-159]. At present, several butanol-tolerant strains have been obtained through classical chemical mutagenesis, continuous culture, and serial enrichment procedures [21, 160]. Unfortunately, many tolerant strains did not correspondingly display an improved capacity to produce butanol. More importantly, the molecular mechanism underlying butanol tolerance is still not comprehensively understood, making it difficult to further improve clostridia $[48,161]$.

\section{Engineering individual genes or enzymes}

As an effective strategy, the gsh AB genes, coding for $\gamma$-glutamate-cysteine ligase and glutathione synthetase, could be explored to improve cellular robustness. The overexpression of gsh $\mathrm{AB}$ genes gave a more robust phenotype of $C$. acetobutylicum with butanol resistance and aerotolerance [83]. More importantly, with the combination of disrupting $a d c$ and overexpressing the gsh $\mathrm{AB}$ cassette, the cellular robustness and fermentation performance were correspondingly enhanced, so that the production of butanol increased from 5.17 to $14.86 \mathrm{~g} / \mathrm{L}$ with the cost being acetone production, which decreased from 2.64 to $0.15 \mathrm{~g} / \mathrm{L}$ [162]. Furthermore, knocking-out a histidine kinase (cac 3319) effectively improved the cellular performance of $C$. acetobutylicum, so that the butanol titer and productivity increased from 12.6 to $18.2 \mathrm{~g} / \mathrm{L}$ and 0.20 to $0.38 \mathrm{~g} / \mathrm{L} / \mathrm{h}$, respectively, due to the enhancement of butanol tolerance [93, 163]. Similarly, a mutation in the $a d h E$ gene (D494G) was the key factor for several tolerant strains, as re-introducing the $a d h E$ gene (D494G) effectively increased cellular tolerance against several primary alcohols, such as butanol, isobutanol, and ethanol [164].

\section{Transcriptional regulators}

As an alternative strategy, several molecular chaperones, including groES, dnaKJ, hsp18, and hsp90, have been identified and characterized as potential target genes to improve cellular tolerance $[152,165,166]$ (Table 2). For example, with the overexpression of GroESL and DnaK, derived from the extremely radio-resistant bacterium Deinococcus wulumuqiensis R12, the recombinant strains [designated 824 (dnaK R12) and 824 (groESL R12)] had higher tolerances against various stresses (such as butanol, furfural, oxidation, and acid), and produced $13.0 \mathrm{~g} / \mathrm{L}$ and $11.2 \mathrm{~g} / \mathrm{L}$ of butanol with increases of $49.4 \%$ and $28.7 \%$ compared to the parent strain, respectively [165]. Moreover, a genomic library was constructed to enrich genes involving butanol tolerance under increased butanol stress conditions, and the most enriched gene (CAC1869) contributed to an array of tolerance mechanisms, in which overexpression significantly increased butanol tolerance by more than $80 \%$ [149]. 


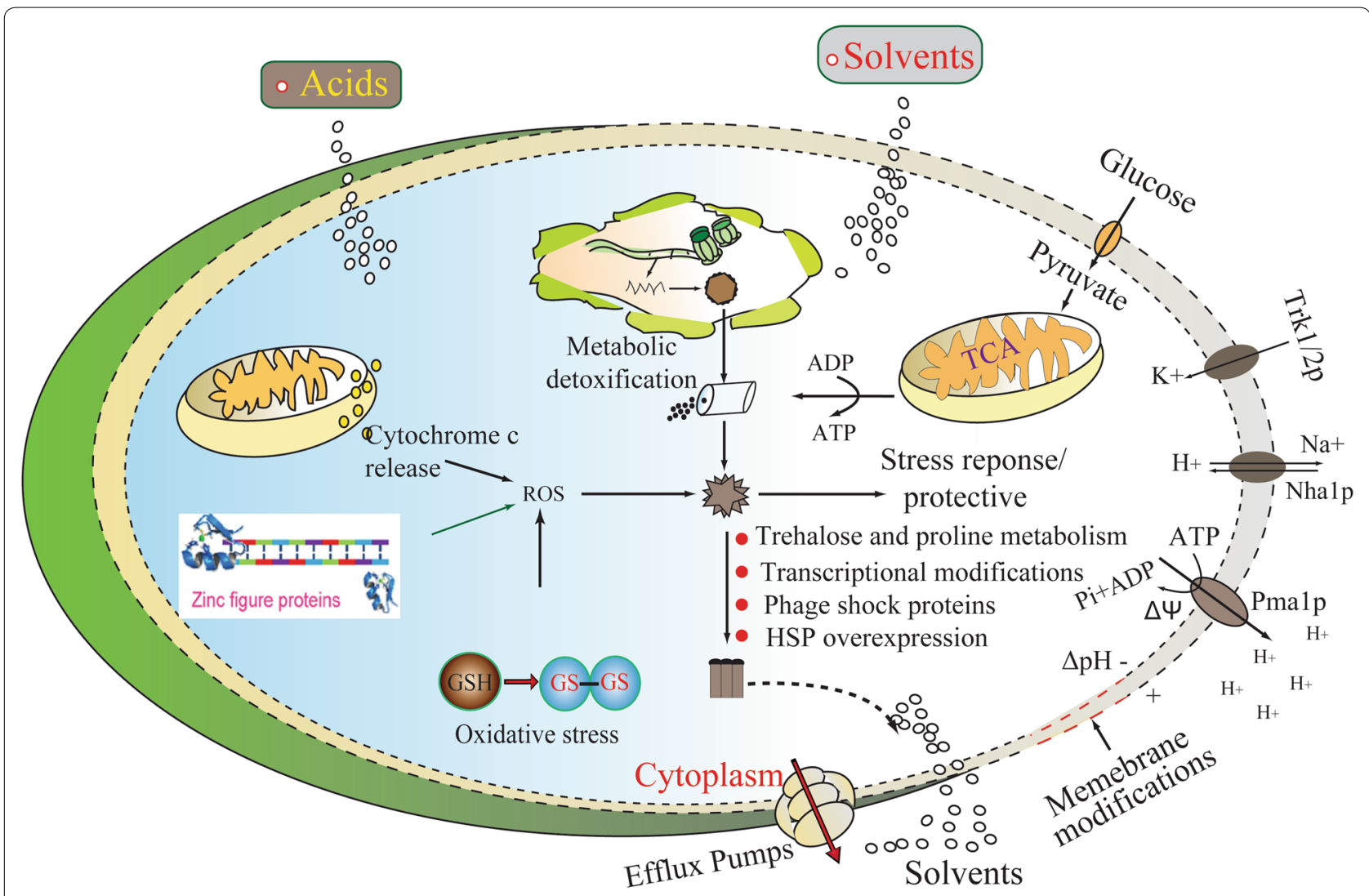

Fig. 4 Schematic diagram showing a prototype of environmental tolerance mechanisms in clostridia

However, it should be noted that overexpression of HSP genes (e.g., grpE and $h t p \mathrm{G}$ ) effectively improved cellular robustness, but also significantly impaired solvent production, indicating that butanol tolerance and production capabilities are not necessarily linked together [167]. More interestingly, some negative control factors against butanol resistance were also described in clostridia, in which two adjacent genes of unknown functions were characterized by the comparative proteomic analysis. Inactivation of either or both genes effectively decreased sensitivity towards butanol stress, but overexpression of both genes inhibited cell growth in 1\% butanol [168].

\section{Improvement of fermentation processes for $A B E$ fermentation}

Apart from modifications at the microbial level, engineering the fermentation process itself is another effective strategy for alleviating butanol toxicity and enhancing butanol production. At present, various fermentation processes, which determine capital investment in the upstream and downstream processes, feedstock consumption, and energy requirements, have been developed to further improve the efficiency of $\mathrm{ABE}$ fermentation.

\section{Optimization of culture conditions \\ Effects of exogenous additives on ABE fermentation}

According to the metabolic pathway and physiological characteristics, various organic acids (such as acetate, butyrate, amino acids, and lactic acid) could serve as alternative substrates for butanol production, and then maintain the robust expression of enzymes associated during the solventogenic and solventogenesis phase $[169,170]$. Interestingly, when butyrate was the sole carbon source, only $0.2 \mathrm{~g} / \mathrm{L}$ of butanol was produced, but the production of butanol significantly increased to $10 \mathrm{~g} / \mathrm{L}$ when both butyric acid and glucose were present, suggesting that butyric acid may be an important factor triggering solvent production [171]. More importantly, after optimization of the glucose concentration, butyric acid addition, and $\mathrm{C} / \mathrm{N}$ ratio, the amounts of butanol and $\mathrm{ABE}$ production were further increased to $17 \mathrm{~g} / \mathrm{L}$ and $21.71 \mathrm{~g} / \mathrm{L}$, respectively, in the scale-up fermentation of C. acetobutylicum YM1 [172, 173]. Similarly, with the addition of $30 \mathrm{mM}$ ammonium 
acetate, the fermentation time of $C$. acetobutylicum EA was shortened about $12 \mathrm{~h}$, and the yield of butanol increased from 8.3 to $13 \mathrm{~g} / \mathrm{L}$ [174].

Generally, based on the critical micelle concentration, surfactants could self-assemble and into micelles, and then relieve the butanol toxicity against microorganisms by entrapping the butanol into micelles. To the end, adding surfactant was used to significantly improve the performance of ABE fermentation. Butanol is coated with surfactant to slow down its toxicity to microorganisms, so as to enhance butanol production. For instance, with the addition of non-ionic surfactant [3\% ( $/ \mathrm{v} / \mathrm{v})$ L62], the amounts of butanol and total solvents produced correspondingly increased to $15.3 \mathrm{~g} / \mathrm{L}$ and $21 \mathrm{~g} / \mathrm{L}$, which were, respectively, $43 \%$ $(\mathrm{w} / \mathrm{w})$ and $55 \%(\mathrm{w} / \mathrm{w})$, higher than the control. More interestingly, when the surfactant was added at $9 \mathrm{~h}$, the productivities of butanol and total solvent further increased to $0.31 \mathrm{~g} / \mathrm{L} / \mathrm{h}$ and $0.39 \mathrm{~g} / \mathrm{L} / \mathrm{h}$ from $0.13 \mathrm{~g} / \mathrm{L} / \mathrm{h}$ and $0.17 \mathrm{~g} / \mathrm{L} / \mathrm{h}$, respectively [175]. Likewise, a combined zinc-supplemented/magnesium-starved fermentation medium could also effectively improve central carbon metabolism through multi-level modulation, e.g., up-regulation of glycolytic pathway, up-regulation in thiolase, butyraldehyde dehydrogenase and butanol dehydrogenase, and down-regulation in alcohol dehydrogenase, and then enhanced glucose utilization, reduced ethanol production and induced solventogenesis earlier, making the production of butanol increased from 11.83 to $19.18 \mathrm{~g} / \mathrm{L}$ [176].

\section{Mixed cultivation for ABE fermentation}

To further enhance the economic feasibility of $A B E$ fermentation, mixed cultures with different microorganisms were developed to: (1) enlarge the range of substrates [177]; (2) increase the availability of intermediates $[178,179]$, and (3) decrease the cost of maintaining strict anaerobic conditions [180]. For instance, to eliminate the costly enzymatic hydrolysis step, a mixed culture of C. thermocellum and C. acetobutylicum was used for $\mathrm{ABE}$ fermentation, in which $40 \mathrm{~g} / \mathrm{L}$ cellulose was directly utilized to produce $5.8 \mathrm{~g} / \mathrm{L}$ butanol [181]. Similarly, when a mixed culture of $C$. acetobutylicum and $B$. subtilis without anaerobic treatment was used to reduce the application of costly reducing agents, $14.9 \mathrm{~g} / \mathrm{L}$ of butanol was produced, which was $21.1 \%$ higher than that from a pure culture of C. acetobutylicum [182]. However, the greater possibility of infection by a bacteriophage when the number of transfer/ sub-culturing steps is increased has become the major drawback, which has restricted the industrial application of co-culture systems.

\section{Regulating the oxidation-reduction potential (ORP) for $A B E$ fermentation}

As shown in Fig. 1, a high level of NADH enhances butanol production at the expense of reduced acetone formation, suggesting that manipulating the intracellular redox balance at the molecular level or of the fermentation process may be an effective pathway to drive more carbon flux and energy towards butanol production [183, 184].

Intracellular regulators for redox balance For clostridia, the electron flow is primarily regulated at the ferredoxin/ hydrogenase node, so that reducing hydrogenase activities could effectively inhibit molecular hydrogen formation, driving electron flow towards butanol due to the regeneration of the $\mathrm{NAD}(\mathrm{P})^{+}$pool [185]. Therefore, overexpressing NADH-dependent adhE2 could effectively regulate the redox rebalance, and subsequently further improve butanol production [80]. Similarly, Rex, a redoxsensing protein and transcriptional regulator, could effectively regulate the expression of genes involved in butanol pathways against the intracellular $\mathrm{NADH} / \mathrm{NAD}^{+}$shift. As a result, a Rex-negative mutant produced greater amounts of ethanol and butanol with less hydrogen and acetone as by-products [186].

Bioprocess engineering Compared to the tedious task of genetic modification, bioprocess engineering (such as adding an electron carrier to strengthen NADH synthesis or aerating with $\mathrm{CO}$ to repress hydrogenases) could be explored with an immediate impact on environmental and intracellular ORP [187]. To this end, some artificial electron carriers (such as methyl viologen and neutral red) were added to drive the carbon flow from acids to alcohols: adding $2 \mathrm{~g} / \mathrm{L}$ of $\mathrm{Na}_{2} \mathrm{SO}_{4}$ (an electron receptor) significantly increased butanol production, which reached $12.96 \mathrm{~g} / \mathrm{L}, 34.8 \%$ higher than that of the control [188]. Likewise, when a mixture of $85 \% \mathrm{~N}_{2}$ and $15 \% \mathrm{CO}$ was sparged during the $\mathrm{ABE}$ fermentation, hydrogenase activity and electron transfer were effectively suppressed, but the cellular $\mathrm{NAD}(\mathrm{P}) \mathrm{H}$ pool was significantly increased, improving the production of butanol from 4.8 to $7.8 \mathrm{~g} / \mathrm{L}$ [189]. More interestingly, when the ORP of ABE fermentation was regulated at $-290 \mathrm{mV}$, solvent production could be initiated earlier, increasing solvent productivity by $35 \%$, but the butanol yield was only slightly increased compared with that without ORP control [190].

\section{Optimization of the fermentation process High-cell-density fermentation}

Compared to aerobic fermentations, fermentations with clostridia have excellent specific carbon fluxes [103], but 
suffer from low cell density [a maximum absorbance of around $10-11$ at $\left.600 \mathrm{~nm}\left(\mathrm{~A}_{600}\right)\right]$ due to product inhibition, some unknown quorum-sensing mechanism, or unsuitable bioreactor operation [191-193]. To this end, various fermentation processes (e.g., immobilized cell, batch, fed-batch, and continuous) have been developed to realize a high-cell-density fermentation by alleviating substrate and product inhibitions [33, 93] (Table 4).

Compared to fed-batch and batch fermentations (characterized by product inhibition and considerable down time) and despite a few disadvantages (such as high capital cost, phage contamination, and flocculation of bacterial growth), continuous processes (using free cells, immobilized cells, and cell recycling) offer a more attractive and productive alternative for commercial industrial $\mathrm{ABE}$ production. The various advantages include reductions in sterilization and re-inoculation times, superior productivity, and fewer substrate and butanol inhibitions [194]. For example, with the help of membrane cell-recycle bioreactor, a high cell density continuous ABE fermentation of $C$. acetobutylicum BKM19 was carried out to produce butanol and $\mathrm{ABE}$ with the volumetric productivities of 10.7 and $21.1 \mathrm{~g} / \mathrm{L} / \mathrm{h}$, the production of 11.9 and
$23.5 \mathrm{~g} / \mathrm{L}$, and the yields of 0.17 and $0.34 \mathrm{~g} / \mathrm{g}$, respectively, under the optimal operational condition [195]. Generally, a productivity of $>10 \mathrm{~g} / \mathrm{L} / \mathrm{h}$, titer of $>10 \mathrm{~g} / \mathrm{L}$ butanol, and yield up to $0.44 \mathrm{~g} / \mathrm{g}$ could be achieved from a high-celldensity fermentation, a great success in $\mathrm{ABE}$ fermentation by Clostridium $[196,197]$.

\section{In situ product recovery (ISPR) techniques}

To further alleviate butanol toxicity, several in situ product recovery (ISPR) techniques, including pervaporation, adsorption, liquid-liquid extraction, and gas stripping, were also developed to integrate with the fermentation process for higher butanol productivity [198-202] (Table 5). For example, with the combination of fed-batch fermentation and gas stripping, the production, productivity, and yield of total solvent significantly increased to $233 \mathrm{~g}, 1.16 \mathrm{~g} / \mathrm{L} / \mathrm{h}$, and $0.47 \mathrm{~g} / \mathrm{g}$, respectively [203]. However, there are several advantages and disadvantages of each recovery system for butanol production (Table 5). Reverse osmosis seemed to be the most preferable recovery technique from an economic point of view, but it is prone to membrane clogging or fouling [204]. Recently, a series of novel composite membranes (such as FAS

Table 4 Comparison of different fermentation processes for butanol production

\begin{tabular}{|c|c|c|c|c|c|c|}
\hline Fermentation process & Strain & Substrates & Yield (g/g) & Productivity (g/L/h) & Titer of $A B E(g / L)$ & Refs. \\
\hline \multirow[t]{2}{*}{ Batch fermentation } & C. beijerinckii P260 & Barley straw & 0.43 & 0.39 & 26.46 & [239] \\
\hline & C. beijerinckii BA101 & Corn fibers & $0.36-0.39$ & 0.10 & 9.3 & {$[33]$} \\
\hline \multirow[t]{2}{*}{ Fed-batch fermentation } & C. beijerinckii P260 & Wheat straw & - & 0.36 & 16.59 & [240] \\
\hline & $\begin{array}{l}\text { C. saccharoperbutylacetoni- } \\
\text { cum N1-4 }\end{array}$ & $\begin{array}{l}\text { Synthetic medium with } \\
\text { butyric acid }\end{array}$ & 0.49 & 0.42 & 16.0 & [241] \\
\hline \multicolumn{7}{|l|}{ Continuous fermentation } \\
\hline \multirow[t]{2}{*}{$\begin{array}{l}\text { (i) Free cell continuous } \\
\text { fermentation }\end{array}$} & $\begin{array}{l}\text { C. saccharobutylicum DSM } \\
13864\end{array}$ & Sago starch & 0.29 & 0.85 & 9.1 & [242] \\
\hline & C. beijerinckii BA101 & Degermed corn & - & $0.29-0.30$ & 14.28 & [194] \\
\hline \multirow[t]{2}{*}{$\begin{array}{l}\text { (ii) Immobilized cells con- } \\
\text { tinuous fermentation }\end{array}$} & $\begin{array}{l}\text { C. acetobutylicum ATCC } \\
55025\end{array}$ & Corn & 0.42 & 4.6 & 12.5 & [243] \\
\hline & C. beijerinckii BA101 & Synthetic medium & 0.36 & 12.43 & 8.8 & [244] \\
\hline \multirow[t]{2}{*}{$\begin{array}{l}\text { (iii) Cell recycling and } \\
\text { bleeding }\end{array}$} & $\begin{array}{l}\text { C. saccharoperbutylacetoni- } \\
\text { cum N14 }\end{array}$ & Synthetic medium & - & 11.0 & 8.58 & [245] \\
\hline & C. acetobutylicum BKM19 & $\begin{array}{l}\text { Clostridial growth medium } \\
\text { (CGM) }\end{array}$ & 0.34 & 21.1 & 23.5 & [195] \\
\hline \multicolumn{7}{|l|}{ In situ product recovery } \\
\hline \multicolumn{7}{|l|}{ (i) Adsorption process } \\
\hline Fed-batch fermentation & C. acetobutylicum ATCC 824 & Glucose & 0.22 & 0.45 & 54.6 & [246] \\
\hline \multicolumn{7}{|l|}{ (ii) Pervaporation process } \\
\hline Batch fermentation & C. acetobutylicum ATCC 824 & Glucose & 0.38 & 0.76 & 201.8 & [247] \\
\hline \multicolumn{7}{|l|}{ (iii) Gas stripping process } \\
\hline Batch fermentation & C. acetobutylicum JB200 & $\begin{array}{l}\text { Cassava bagasse hydro- } \\
\text { lysate }\end{array}$ & 0.23 & 0.32 & 108.5 & [248] \\
\hline Batch fermentation & C. beijerinckii BA101 & Glucose & 0.47 & 0.61 & 75.9 & [249] \\
\hline Fed-batch fermentation & C. beijerinckii BA101 & Glucose & 0.47 & 1.16 & 233 & [138] \\
\hline
\end{tabular}




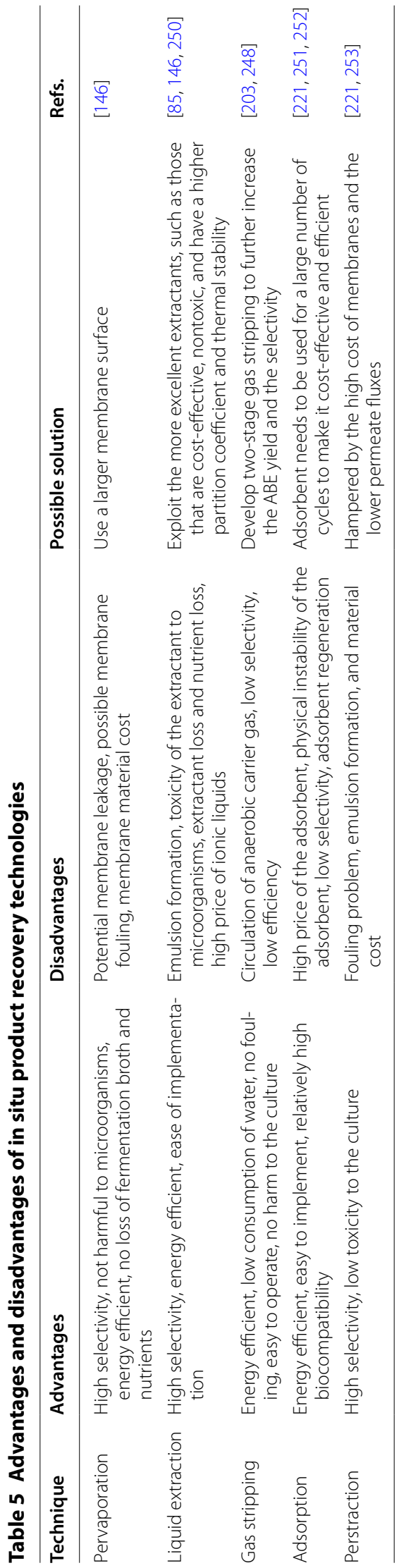


cross-linked PDMS [205], PDMS-based pervaporation membranes [206], modified grapheme oxide with ionic liquid [207], and mixed matrix membranes [208]) were fabricated and applied to ISPR techniques, and displayed a more stable performance during long-time continuous operation of $\mathrm{ABE}$ fermentation [24]. More importantly, an ideal integrated recovery process should minimize energy consumption and concentrate butanol with high selectivity, so hybrid integrated recovery processes were also developed to compensate for the respective disadvantages of individual processes, and showed good potential for industrial ABE fermentation [191, 209].

\section{Engineering clostridia for other high value-added products}

Acetone, the least attractive by-product, can be reduced to isopropanol through isopropanol-butanol-ethanol (IBE) fermentation, providing an ideal platform for direct utilization without prior separation of the solvents [210]. As shown in Fig. 5, with a combination of introducing the $s a d h$ gene and overexpressing the $\operatorname{ctf} A, \operatorname{ctf} B$, and adc genes, $C$. acetobutylicum could be engineered to be a typical IBE producer, so that $24.4 \mathrm{~g} / \mathrm{L}$ IBE with a yield of $0.35 \mathrm{~g} / \mathrm{g}$ glucose was produced by batch fermentation [211]. More importantly, when the genes sadh and hydG (putative electron transfer protein) were introduced into the hyper-ABE-producing C. acetobutylicum BKM19, $27.9 \mathrm{~g} / \mathrm{L}$ of IBE with a yield of $0.29 \mathrm{~g} / \mathrm{g}$ glucose were produced even without engineering the acetone pathway [212].

Additionally, C. tyrobutyricum, C. butyricum, C. acetobutylicum, and C. thermobutyricum could also be engineered as cell factories for producing butyric acid [213, 214]. When the $b u k, p t a$, and $c t f B$ genes were knocked out in $C$. acetobutylicum, the butyric acid selectivity (BA/AA ratio) significantly increased to $14.3 \mathrm{~g} / \mathrm{g}$, but the production of butyric acid was only $23.8 \mathrm{~g} / \mathrm{L}$ [91]. On this basis, a higher butyric acid selectivity could be obtained by increasing the NADH-driving force, as the pta-ctfB-buk-adhE1-hydA-deficient strain could produce $32.5 \mathrm{~g} / \mathrm{L}$ of butyric acid with a yield of $0.41 \mathrm{~g} / \mathrm{g}$, a productivity of $0.89 \mathrm{~g} / \mathrm{L} / \mathrm{h}$, and a BA/AA ratio of $31.3 \mathrm{~g} / \mathrm{g}$

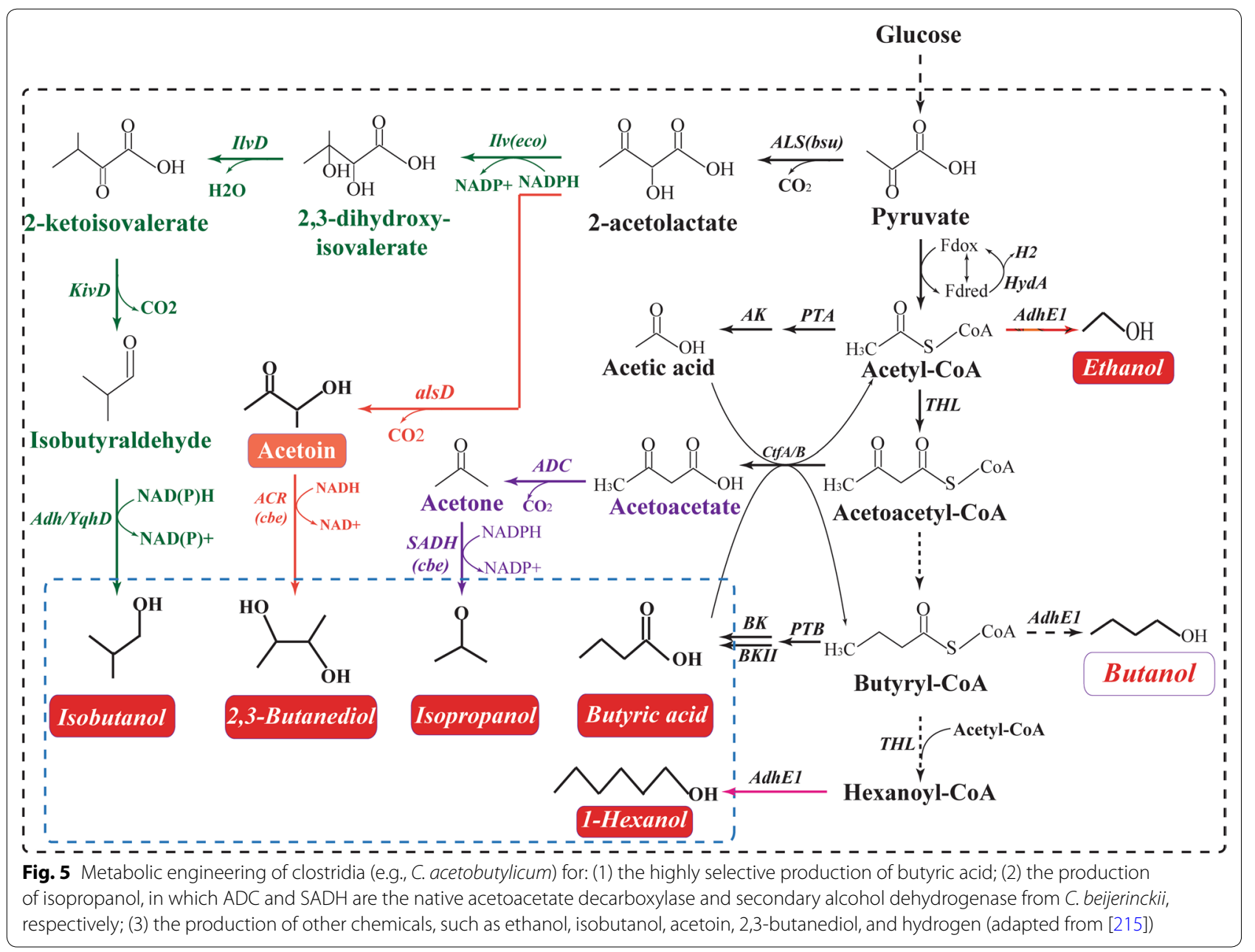


[91]. More importantly, with the development of interdisciplinary processes, the sole product or even the mixture produced by the $\mathrm{ABE}$ fermentation process can be further converted into high value-added products, such as 2,3-butanediol, short-chain esters, higher-molecular mass alkanes, riboflavin, and hydrogen, through enzymatic or chemical catalysis [215, 216] (Fig. 5).

\section{Conclusions and future prospects}

An important bulk chemical, butanol has been attracting increasing interest from academic and industrial researchers. Over the past 100 years, great progress in strain improvement has been made through systems metabolic engineering integrated with process optimization [191]. However, ABE fermentation is an extraordinarily complex metabolic process with a large network of metabolic reactions as well as an associated gene regulatory program and environmental cues. Little is known about how the metabolic shift from acid to solvent production is regulated on the molecular level, making identification of the inducing signals, how many regulators are involved, and how regulator interactions are connected major topics for research [217-219]. Unfortunately, ABE fermentation is still not economically viable due to the high cost of feedstock, low butanol titer, and butanol toxicity [220, 221], and as butanol production still remains at low levels $(<21 \mathrm{~g} / \mathrm{L})$ and cannot compete with ethanol production $(100 \mathrm{~g} / \mathrm{L})$ in batch fermentation mode [216].

In the future, to further improve the economic feasibility of $\mathrm{ABE}$ fermentation, multidirectional endeavors should probably continue to depend on a three-pronged approach that involves the upstream (strain development), midstream (innovative and advanced fermentation strategies), and downstream (in situ recovery and other cost-effective recovery) processes:

- Considering the intrinsic complexity of the metabolic network, targeting global regulators, transcription factors, and chaperones to further improve cellular performance (i.e., superior butanol tolerance, abandonment of sporulation, utilization of inexpensive carbon substrate, a single product (butanol) and higher butanol titer) at the global level.

- Constructing an excellent non-natural host to perfectly address the issues of low butanol tolerance and butanol yield, and poor utilization of low-cost substrates by integrating systems biology and synthetic biology.

- Developing and optimizing the butanol bioprocess by integrating fermentation and downstream processes, especially coupling with in situ methods for solvent extraction and recovery processes, such as gas strip- ping, advanced membrane separation with super critical extraction.

- Comprehensive application of fermentation by-products (large wastewater streams, cell mass, $\mathrm{CO}_{2}$, and $\mathrm{H}_{2}$ ) or in situ conversion of $\mathrm{ABE}$ into more valueadded products through biological or chemical catalysis.

\section{Abbreviations}

ABE: Acetone-butanol-ethanol; AAD: Aldehyde/alcohol dehydrogenase; ATP: Adenosine triphosphate; CoA: Coenzyme A; CRISPR: Clustered regularly interspaced short palindromic repeats; EMP: Embden-Meyerhof-Parnas; GSMMs: Genome-scale metabolic models; HSP: Heat shock stress proteins; IBE: Isopropanol-butanol-ethanol; NAD(P)H/NAD(P) ${ }^{+}$: Reduced/oxidized nicotinamide adenine dinucleotide (phosphate) ratio; ORP: Oxidation-reduction potential; PTS: Phosphotransferase system; PPP: Pentose phosphate pathway; U/S: Unsaturated-to-saturated fatty acids ratio.

\section{Acknowledgements}

This work was financially supported by the National Natural Science Foundation of China (31560027), Guangxi Natural Science Foundation (2017GXNSFAA198297), and the "Bagui Young Scholars" Special Project.

\section{Authors' contributions}

SBL, LH and CZK made contribution to the design of the study, the acquisition of data, the analysis and interpretation of data and contributed to the manuscript writing. ZWP and LML conceived and organized the study and helped to draft the manuscript, and revised the manuscript. All the authors read and approved the final manuscript.

\section{Funding}

National Natural Science Foundation of China (31560027), Guangxi Natural Science Foundation (2017GXNSFAA198297), and the "Bagui Young Scholars" Special Project.

\section{Availability of supporting data}

Not applicable.

Ethical approval and consent to participate

Not applicable.

Consent for publication

All authors agreed to publish this article.

\section{Competing interests}

The authors declare that they have no competing interests.

\section{Author details}

${ }^{1}$ College of Light Industry and Food Engineering, Guangxi University, Nanning 530004, China. ${ }^{2}$ College of Life Science and Technology, Guangxi University, Nanning 530005, China. ${ }^{3}$ State Key Laboratory of Food Science and Technology, Jiangnan University, Wuxi 214122, China.

Received: 17 September 2019 Accepted: 4 February 2020

Published online: 06 March 2020

\section{References}

1. Li Y, Tang W, Chen Y, Liu J, Chia-fon FL. Potential of acetone-butanolethanol (ABE) as a biofuel. Fuel. 2019;242:673-86.

2. Hill J, Nelson E, Tilman D, Polasky S, Tiffany D. Environmental, economic, and energetic costs and benefits of biodiesel and ethanol biofuels. Proc Natl Acad Sci USA. 2006;103(30):11206-10. 
3. Green EM. Fermentative production of butanol-the industrial perspective. Curr Opin Biotechnol. 2011;22(3):337-43.

4. Xue C, Zhao J, Chen L, Yang S-T, Bai F. Recent advances and state-of-theart strategies in strain and process engineering for biobutanol production by Clostridium acetobutylicum. Biotechnol Adv. 2017;35(2):310-22.

5. Algayyim SJM, Wandel AP, Yusaf T, Hamawand I. Production and application of ABE as a biofuel. Renew Sustain Energy Rev. 2018;82:1195-214.

6. Al-Shorgani NKN, Isa MHM, Yusoff WMW, Kalil MS, Hamid AA. Isolation of a Clostridium acetobutylicum strain and characterization of its fermentation performance on agricultural wastes. Renew Energy. 2016;86:459-65.

7. Papoutsakis ET. Engineering solventogenic clostridia. Curr Opin Biotechnol. 2008;19(5):420-9.

8. Wang Y, Ho S-H, Yen H-W, Nagarajan D, Ren N-Q, Li S, Hu Z, Lee D-J, Kondo A, Chang J-S. Current advances on fermentative biobutanol production using third generation feedstock. Biotechnol Adv. 2017;35(8):1049-59

9. Jones DT, Woods DR. Acetone-butanol fermentation revisited. Microbio Rev. 1986;50(4):484.

10. Jiang Y, Liu J, Jiang W, Yang Y, Yang S. Current status and prospects of industrial bio-production of n-butanol in China. Biotechnol Adv. 2015;33(7):1493-501.

11. Gu Y, Jiang Y, Wu H, Liu X, Li Z, Li J, Xiao H, Shen Z, Dong H, Yang Y, et al. Economical challenges to microbial producers of butanol: feedstock, butanol ratio and titer. Biotechnol J. 2011;6(11):1348-57.

12. Bram S, De Ruyck J, Lavric D. Using biomass: a system perturbation analysis. Appl Energy. 2009;86(2):194-201.

13. Jin Q, Qureshi $\mathrm{N}$, Wang $\mathrm{H}$, Huang $\mathrm{H}$. Acetone-butanol-ethanol (ABE) fermentation of soluble and hydrolyzed sugars in apple pomace by Clostridium beijerinckii P260. Fuel. 2019;244:536-44.

14. Shen CR, Lan El, Dekishima Y, Baez A, Cho KM, Liao JC. Driving forces enable high-titer anaerobic 1-butanol synthesis in Escherichia coli. Appl Environ Microbiol. 2011;77(9):2905-15.

15. Gheshlaghi R, Scharer J, Moo-Young M, Chou C. Metabolic pathways of clostridia for producing butanol. Biotechnol Adv. 2009;27(6):764-81.

16. Lütke-Eversloh T. Application of new metabolic engineering tools for Clostridium acetobutylicum. Appl Environ Microbiol. 2014:98(13):5823-37.

17. Liu C-G, Xue C, Lin Y-H, Bai F-W. Redox potential control and applications in microaerobic and anaerobic fermentations. Biotechnol Adv. 2013;31(2):257-65.

18. Vivek N, Nair LM, Mohan B, Nair SC, Sindhu R, Pandey A, Shurpali N, Binod P. Bio-butanol production from rice straw-recent trends, possibilities, and challenges. Bioresour Technol Rep. 2019;7:1-14.

19. Abo BO, Gao M, Wang Y, Wu C, Wang Q, Ma H. Production of butanol from biomass: recent advances and future prospects. Environ Sci Pollut Res. 2019;26:20164-82.

20. Callegari A, Bolognesi S, Cecconet D, Capodaglio AG. Production technologies, current role, and future prospects of biofuels feedstocks: a state-of-the-art review. Crit Rev Environ Sci Technol. 2020;50(4):384-36.

21. Liu S, Qureshi N. How microbes tolerate ethanol and butanol. N Biotechnol. 2009;26(3-4):117-21.

22. Ezeji T, Milne C, Price ND, Blaschek HP. Achievements and perspectives to overcome the poor solvent resistance in acetone and butanol-producing microorganisms. Appl Microbiol Biotechnol. 2010;85(6):1697-712.

23. Zheng J, Tashiro Y, Wang Q, Sonomoto K. Recent advances to improve fermentative butanol production: genetic engineering and fermentation technology. J Biosci Bioeng. 2015;119(1):1-9.

24. Stoller M, Bravi M, Russo P. Development of a process for $n$-butanol recovery from abe wastewater streams by membrane technology. Chem Eng Trans. 2019;74:937-42.

25. Moon HG, Jang Y-S, Cho C, Lee J, Binkley R, Lee SY. One hundred years of clostridial butanol fermentation. FEMS Microbiol Lett. 2016;363(3):1-15.

26. Azimi $\mathrm{H}$, Thibault J, Tezel FH. Separation of butanol using pervaporation: a review of mass transfer models. J Fluid Flow Heat Mass Transf JFFHMT. 2019;5(4):53-82

27. Jang Y-S, Lee J, Malaviya A, Seung DY, Cho JH, Lee SY. Butanol production from renewable biomass: rediscovery of metabolic pathways and metabolic engineering. Biotechnol J. 2012;7(2):186-98.
28. Koepke M, Held C, Hujer S, Liesegang H, Wiezer A, Wollherr A, Ehrenreich A, LiebI W, Gottschalk G, Duerre P. Clostridium ljungdahlii represents a microbial production platform based on syngas. Proc Natl Acad Sci USA. 2010;107(29):13087-92.

29. Tracy BP, Jones SW, Fast AG, Indurthi DC, Papoutsakis ET. Clostridia: the importance of their exceptional substrate and metabolite diversity for biofuel and biorefinery applications. Curr Opin Biotechnol. 2012;23(3):364-81.

30. Huang H, Liu H, Gan Y-R. Genetic modification of critical enzymes and involved genes in butanol biosynthesis from biomass. Biotechnol Adv. 2010;28(5):651-7.

31. Keis $S$, Shaheen $R$, Jones DT. Emended descriptions of Clostridium acetobutylicum and Clostridium beijerinckii, and descriptions of Clostridium saccharoperbutylacetonicum sp. nov. and Clostridium saccharobutylicum sp. nov. Int J Syst Evol Microbiol. 2001;51:2095-103.

32. Liu Z, Ying Y, Li F, Ma C, Xu P. Butanol production by Clostridium beijerinckii ATCC 55025 from wheat bran. J Ind Microbiol Biotechnol. 2010:37(5):495-501.

33. Qureshi N, Ezeji TC, Ebener J, Dien BS, Cotta MA, Blaschek HP. Butanol production by Clostridium beijerinckii. Part l: use of acid and enzyme hydrolyzed corn fiber. Bioresource Technology. 2008;99(13):5915-22.

34. Atsumi S, Cann AF, Connor MR, Shen CR, Smith KM, Brynildsen MP, Chou KJ, Hanai T, Liao JC. Metabolic engineering of Escherichia coli for 1-butanol production. Metab Eng. 2008;10(6):305-11.

35. Steen EJ, Chan R, Prasad N, Myers S, Petzold CJ, Redding A, Ouellet M, Keasling JD. Metabolic engineering of Saccharomyces cerevisiae for the production of n-butanol. Microb Cell Fact. 2008:7(1):1-8.

36. Nielsen DR, Leonard E, Yoon S-H, Tseng H-C, Yuan C, Prather KLJ. Engineering alternative butanol production platforms in heterologous bacteria. Metab Eng. 2009;11(4-5):262-73.

37. Lee SK, Chou H, Ham TS, Lee TS, Keasling JD. Metabolic engineering of microorganisms for biofuels production: from bugs to synthetic biology to fuels. Curr Opin Biotechnol. 2008;19(6):556-63.

38. Mainguet $\mathrm{SE}$, Gronenberg LS, Wong SS, Liao JC. A reverse glyoxylate shunt to build a non-native route from C-4 to C-2 in Escherichia coli. Metab Eng. 2013;19:116-27.

39. Dong H, Zhao C, Zhang T, Zhu H, Lin Z, Tao W, Zhang Y, Li Y. A systematically chromosomally engineered Escherichia coli efficiently produces butanol. Metab Eng. 2017;44:284-92.

40. Duerre P. Fermentative butanol production—bulk chemical and biofuel. In: Wiegel J, Maier RJ, Adams MWW, editors. Incredible anaerobes: from physiology to genomics to fuels, vol. 1125. Boston: Blackwell; 2008. p. 353-62.

41. Zheng Y-N, Li L-Z, Xian M, Ma Y-J, Yang J-M, Xu X, He D-Z. Problems with the microbial production of butanol. J Ind Microbiol Biotechnol. 2009:36(9):1127-38.

42. Lütke-Eversloh T, Bahl H. Metabolic engineering of Clostridium acetobutylicum: recent advances to improve butanol production. Curr Opin Biotechnol. 2011:22(5):634-47.

43. Jiang $Y, X u C$, Dong F, Yang $Y$, Jiang $W$, Yang S. Disruption of the acetoacetate decarboxylase gene in solvent-producing Clostridium acetobutylicum increases the butanol ratio. Metab Eng. 2009;1 1(4-5):284-91.

44. Zhao YS, Tomas CA, Rudolph FB, Papoutsakis ET, Bennett GN. Intracellular butyryl phosphate and acetyl phosphate concentrations in Clostridium acetobutylicum and their implications for solvent formation. Appl Environ Microbiol. 2005;71(1):530-7.

45. Wang S, Zhang Y, Dong H, Mao S, Zhu Y, Wang R, Luan G, Li Y. Formic acid triggers the "Acid Crash" of acetone-butanol-ethanol fermentation by Clostridium acetobutylicum. Appl Environ Microbiol. 2011:77(5):1674-80

46. Kumar M, Gayen K, Saini S. Role of extracellular cues to trigger the metabolic phase shifting from acidogenesis to solventogenesis in Clostridium acetobutylicum. Biores Technol. 2013;138:55-62.

47. Peabody GL, Kao KC. Recent progress in biobutanol tolerance in microbial systems with an emphasis on Clostridium. FEMS Microbiol Lett. 2016:363(5):fnw017.

48. Grimmler C, Janssen H, Krauße D, Fischer R-J, Bahl H, Dürre P, Liebl W, Ehrenreich A. Genome-wide gene expression analysis of the switch between acidogenesis and solventogenesis in continuous cultures of Clostridium acetobutylicum. J Mol Microbiol Biotechnol. 2011:20(1):1-15. 
49. Jones DT, van der Westhuizen A, Long S, Allcock ER, Reid SJ, Woods DR. Solvent production and morphological changes in Clostridium acetobutylicum. Appl Environ Microbiol. 1982;43(6):1434-9.

50. Hocq R, Bouilloux-Lafont M, Ferreira NL, Wasels F. $\sigma 54(\sigma \mathrm{L})$ plays a central role in carbon metabolism in the industrially relevant Clostridium beijerinckii. Sci Rep. 2019;9(1):7228.

51. Alsaker KV, Papoutsakis ET. Transcriptional program of early sporulation and stationary-phase events in Clostridium acetobutylicum. J Bacteriol. 2005:187(20):7103-18.

52. Al-Hinai MA, Jones SW, Papoutsakis ET. The Clostridium sporulation programs: diversity and preservation of endospore differentiation. Microbiol Mol Biol Rev. 2015;79(1):19-37.

53. Al-Hinai MA, Jones SW, Papoutsakis ET. $\sigma^{\mathrm{k}}$ of Clostridium acetobutylicum is the first known sporulation-specific sigma factor with two developmentally separated roles, one early and one late in sporulation. J Bacteriol. 2014;196(2):287-99.

54. Jones SW, Tracy BP, Gaida SM, Papoutsakis ET. Inactivation of sigma(F) in Clostridium acetobutylicum ATCC 824 blocks sporulation prior to asymmetric division and abolishes sigma(E) and sigma(G) protein expression but does not block solvent formation. J Bacteriol. 2011;193(10):2429-40.

55. Bi C, Jones SW, Hess DR, Tracy BP, Papoutsakis ET. SpollE is necessary for asymmetric division, sporulation, and expression of $\sigma^{F}, \sigma^{E}$, and $\sigma^{G}$ but does not control solvent production in Clostridium acetobutylicum ATCC 824. J Bacteriol. 2011:193(19):5130-7.

56. Tomas CA, Alsaker KV, Bonarius HPJ, Hendriksen WT, Yang H, Beamish JA, Paredes CJ, Papoutsakis ET. DNA array-based transcriptional analysis of asporogenous, nonsolventogenic Clostridium acetobutylicum strains SKO1 and M5. J Bacteriol. 2003;185(15):4539-47.

57. Poehlein A, Hartwich K, Krabben $P$, Ehrenreich A, Liebl W, Dürre $P$, Gottschalk G, Daniel R. Complete genome sequence of the solvent producer Clostridium saccharobutylicum NCP262 (DSM 13864). Genome Announc. 2013;1(6):e00997-13.

58. Wu Y-R, Li Y, Yang K-L, He J. Draft genome sequence of butanolacetone-producing Clostridium beijerinckii strain G1 17. J Bacteriol. 2012;194(19):5470-1.

59. Poehlein A, Solano JDM, Flitsch SK, Krabben P, Winzer K, Reid SJ, Jones DT, Green E, Minton NP, Daniel R. Microbial solvent formation revisited by comparative genome analysis. Biotechnol Biofuels. 2017:10(1):58.

60. Lee J, Yun H, Feist AM, Palsson BØ, Lee SY. Genome-scale reconstruction and in silico analysis of the Clostridium acetobutylicum ATCC 824 metabolic network. Appl Microbiol Biotechnol. 2008;80(5):849-62.

61. Ehsaan M, Kuit W, Zhang Y, Cartman ST, Heap JT, Winzer K, Minton NP. Mutant generation by allelic exchange and genome resequencing of the biobutanol organism Clostridium acetobutylicum ATCC 824. Biotechnol Biofuels. 2016;9(1):4.

62. Bao G, Wang R, Zhu Y, Dong H, Mao S, Zhang Y, Chen Z, Li Y, Ma Y. Complete genome sequence of Clostridium acetobutylicum DSM 1731, a solvent-producing strain with multireplicon genome architecture. J Bacteriol. 2011;193(18):5007-8.

63. Hu S, Zheng H, Gu Y, Zhao J, Zhang W, Yang Y, Wang S, Zhao G, Yang S, Jiang W. Comparative genomic and transcriptomic analysis revealed genetic characteristics related to solvent formation and xylose utilization in Clostridium acetobutylicum EA 2018. BMC Genomics. 2011;12(1):93

64. Jin C, Yao M, Liu H, Chia-fon FL, Ji J. Progress in the production and application of $n$-butanol as a biofuel. Renew Sustain Energy Rev. 2011;15(8):4080-106.

65. Lei Z, Leyn SA, Yang G, Weihong J, Rodionov DA, Chen Y. Ribulokinase and transcriptional regulation of arabinose metabolism in Clostridium acetobutylicum. J Bacteriol. 2012;194(5):1055-64.

66. Lee J, Blaschek HP. Glucose uptake in Clostridium beijerinckii NCIMB 8052 and the solvent-hyperproducing mutant BA101. Appl Environ Microbiol. 2001;67(11):5025-31.

67. Lee J, Mitchell WJ, Tangney M, Blaschek HP. Evidence for the presence of an alternative glucose transport system in Clostridium beijerinckii NCIMB 8052 and the solvent-hyperproducing mutant BA101. Appl Environ Microbiol. 2005;71(6):3384-7.

68. Yang M, Kuittinen S, Zhang J, Vepsalainen J, Keinanen M, Pappinen A. Co-fermentation of hemicellulose and starch from barley straw and grain for efficient pentoses utilization in acetone-butanol-ethanol production. Biores Technol. 2015;179:128-35.
69. Ma K, Hutchins A, Sung S-JS, Adams MW. Pyruvate ferredoxin oxidoreductase from the hyperthermophilic archaeon, Pyrococcus furiosus, functions as a CoA-dependent pyruvate decarboxylase. Proc Natl Acad Sci. 1997;94(18):9608-13.

70. Seedorf $H$, Fricke WF, Veith B, Brueggemann $H$, Liesegang $H$, Strittimatter A, Miethke M, Buckel W, Hinderberger J, Li F, et al. The genome of Clostridium kluyveri, a strict anaerobe with unique metabolic features. Proc Natl Acad Sci USA. 2008;105(6):2128-33.

71. Berrios-Rivera SJ, Bennett GN, San KY. The effect of increasing NADH availability on the redistribution of metabolic fluxes in Escherichia coli chemostat cultures. Metab Eng. 2002;4(3):230-7.

72. Vemuri GN, Eiteman MA, McEwen JE, Olsson L, Nielsen J. Increasing $\mathrm{NADH}$ oxidation reduces overflow metabolism in Saccharomyces cerevisiae. Proc Natl Acad Sci USA. 2007;104(7):2402-7.

73. Inui M, Suda M, Kimura S, Yasuda K, Suzuki H, Toda H, Yamamoto S, Okino S, Suzuki N, Yukawa H. Expression of Clostridium acetobutylicum butanol synthetic genes in Escherichia coli. Appl Microbiol Biotechnol. 2008;77(6):1305-16.

74. Vardar-Schara G, Maeda T, Wood TK. Metabolically engineered bacteria for producing hydrogen via fermentation. Microb Biotechnol. 2008;1 (2):107-25.

75. Li F, Hinderberger J, Seedorf H, Zhang J, Buckel W, Thauer RK. Coupled ferredoxin and crotonyl coenzyme a (CoA) reduction with NADH catalyzed by the butyryl-CoA dehydrogenase/Etf complex from Clostridium kluyveri. J Bacteriol. 2008;190(3):843-50.

76. Cai GQ, Jin B, Saint C, Monis P. Genetic manipulation of butyrate formation pathways in Clostridium butyricum. J Biotechnol. 2011;155(3):269-74.

77. Kim S, Jang Y-S, Ha S-C, Ahn J-W, Kim E-J, Lim JH, Cho C, Ryu YS, Lee SK, Lee SY. Redox-switch regulatory mechanism of thiolase from Clostridium acetobutylicum. Nat Commun. 2015:6(22):8410-21.

78. Ventura J-RS, Hu H, Jahng D. Enhanced butanol production in Clostridium acetobutylicum ATCC 824 by double overexpression of 6-phosphofructokinase and pyruvate kinase genes. Appl Microbiol Biotechnol. 2013;97(16):7505-16.

79. Herrmann G, Jayamani E, Mai G, Buckel W. Energy conservation via electron-transferring flavoprotein in anaerobic bacteria. J Bacteriol. 2008;190(3):784-91.

80. Ma C, Kojima K, Xu N, Mobley J, Zhou L, Yang S-T, Liu XM. Comparative proteomics analysis of high $n$-butanol producing metabolically engineered Clostridium tyrobutyricum. J Biotechnol. 2015;193:108-19.

81. Lan El, Liao JC. ATP drives direct photosynthetic production of 1-butanol in cyanobacteria. Proc Natl Acad Sci USA. 2012;109(16):6018-23.

82. Kihara T, Noguchi T, Tashiro Y, Sakai K, Sonomoto K. Highly efficient continuous acetone-butanol-ethanol production from mixed sugars without carbon catabolite repression. Bioresour Technol Rep. 2019;7:100185.

83. Zhu L, Dong H, Zhang Y, Li Y. Engineering the robustness of Clostridium acetobutylicum by introducing glutathione biosynthetic capability. Metab Eng. 2011;13(4):426-34.

84. Tracy $B P$, Jones $S W$, Papoutsakis ET. Inactivation of $\sigma E$ and $\sigma G$ in Clostridium acetobutylicum illuminates their roles in clostridial-cellform biogenesis, granulose synthesis, solventogenesis, and spore morphogenesis. J Bacteriol. 2011;193(6):1414-26.

85. Nanda S, Golemi-Kotra D, McDermott JC, Dalai AK, Gökalp I, Kozinski JA. Fermentative production of butanol: perspectives on synthetic biology. N Biotechnol. 2017;37:210-21.

86. Li S-B, Qian Y, Liang Z-W, Guo Y, Zhao M-M, Pang Z-W. Enhanced butanol production from cassava with Clostridium acetobutylicum by genome shuffling. World J Microbiol Biotechnol. 2016;32(4):53.

87. Palsson B, Zengler K. The challenges of integrating multi-omic data sets. Nat Chem Biol. 2010;6(11):787-9.

88. Yoo M, Nguyen NP, Soucaille P. Trends in systems biology for the analysis and engineering of Clostridium acetobutylicum metabolism. Trends Microbiol. 2020;28(2):118-40.

89. Gronenberg LS, Marcheschi RJ, Liao JC. Next generation biofuel engineering in prokaryotes. Curr Opin Chem Biol. 2013;17(3):462-71.

90. Heap JT, Kuehne SA, Ehsaan M, Cartman ST, Cooksley CM, Scott JC, Minton NP. The ClosTron: mutagenesis in Clostridium refined and streamlined. J Microbiol Methods. 2010;80(1):49-55. 
91. Jang Y-S, Im JA, Choi SY, Im Lee J, Lee SY. Metabolic engineering of Clostridium acetobutylicum for butyric acid production with high butyric acid selectivity. Metab Eng. 2014;23:165-74.

92. Heap JT, Pennington OJ, Cartman ST, Carter GP, Minton NP. The ClosTron: a universal gene knock-out system for the genus Clostridium. J Microbiol Methods. 2007;70(3):452-64.

93. Xu M, Zhao J, Yu L, Tang I-C, Xue C, Yang S-T. Engineering Clostridium acetobutylicum with a histidine kinase knockout for enhanced n-butanol tolerance and production. Appl Microbiol Biotechnol. 2015;99(2):1011-22.

94. Zhang J, Zong W, Hong W, Zhang Z-T, Wang Y. Exploiting endogenous CRISPR-Cas system for multiplex genome editing in Clostridium tyrobutyricum and engineer the strain for high-level butanol production. Metab Eng. 2018:47:49-59.

95. Wang Y, Zhang Z-T, Seo S-O, Choi K, Lu T, Jin Y-S, Blaschek HP. Markerless chromosomal gene deletion in Clostridium beijerinckii using CRISPR/ Cas9 system. J Biotechnol. 2015;200:1-5.

96. Cho C, Lee SY. Efficient gene knockdown in Clostridium acetobutylicum by synthetic small regulatory RNAs. Biotechnol Bioeng. 2017;114(2):374-83.

97. Senger RS, Papoutsakis ET. Genome-scale model for Clostridium acetobutylicum: part I. Metabolic network resolution and analysis. Biotechnol Bioeng. 2008;101(5):1036-52.

98. Senger RS, Papoutsakis ET. Genome-scale model for Clostridium acetobutylicum: part II. Development of specific proton flux states and numerically determined sub-systems. Biotechnol Bioeng. 2008;101(5):1053-71.

99. Venkataramanan KP, Jones SW, McCormick KP, Kunjeti SG, Ralston MT, Meyers BC, Papoutsakis ET. The Clostridium small RNome that responds to stress: the paradigm and importance of toxic metabolite stress in $C$. acetobutylicum. BMC Genomics. 2013;14(1):849.

100. Wang Q, Venkataramanan KP, Huang H, Papoutsakis ET, Wu CH. Transcription factors and genetic circuits orchestrating the complex multilayered response of Clostridium acetobutylicum to butanol and butyrate stress. BMC Syst Biol. 2013;7(1):120.

101. Luetke-Eversloh T. Application of new metabolic engineering tools for Clostridium acetobutylicum. Appl Microbiol Biotechnol. 2014;98(13):5823-37.

102. Jang Y-S, Lee JY, Lee J, Park JH, Im JA, Eom M-H, Lee J, Lee S-H, Song $\mathrm{H}$, Cho J-H. Enhanced butanol production obtained by reinforcing the direct butanol-forming route in Clostridium acetobutylicum. MBio. 2012;3(5):e00314-12.

103. Harris LM, Blank L, Desai RP, Welker NE, Papoutsakis ET. Fermentation characterization and flux analysis of recombinant strains of Clostridium acetobutylicum with an inactivated solR gene. J Ind Microbiol Biotechnol. 2001:27(5):322-8.

104. Yu H, Chen Z, Wang N, Yu S, Yan Y, Huo Y-X. Engineering transcription factor BmoR for screening butanol overproducers. Metab Eng. 2019:56:28-38.

105. Schiel-Bengelsdorf B, Montoya J, Linder S, Duerre P. Butanol fermentation. Environ Technol. 2013;34(13-14):1691-710.

106. Lee JY, Jang Y-S, Lee J, Papoutsakis ET, Lee SY. Metabolic engineering of Clostridium acetobutylicum M5 for highly selective butanol production. Biotechnol J. 2009;4(10):1432-40.

107. Cho C, Hong S, Moon HG, Jang Y-S, Kim D, Lee SY. Engineering clostridial aldehyde/alcohol dehydrogenase for selective butanol production. MBio. 2019;10(1):e02683-18.

108. Lehmann D, Radomski N, Luetke-Eversloh T. New insights into the butyric acid metabolism of Clostridium acetobutylicum. Appl Microbiol Biotechnol. 2012;96(5):1325-39.

109. Huang J, Du Y, Bao T, Lin M, Wang J, Yang S-T. Production of n-butanol from cassava bagasse hydrolysate by engineered Clostridium tyrobutyricum overexpressing adhE2: kinetics and cost analysis. Bioresour Technol. 2019;292:121969.

110. Abomohra AEF, Elshobary M. Biodiesel, bioethanol, and biobutanol production from microalgae. Microalgae biotechnology for development of biofuel and wastewater treatment. Berlin: Springer; 2019. p. 293-321.

111. Liao JC, Luo M, Pontrelli S, Luo S. Fuelling the future: microbial engineering for the production of sustainable biofuels. Nat Rev Microbiol. 2016;14(5):288-304
112. Jiang Y, Lv Y, Wu R, Sui Y, Chen C, Xin F, Zhou J, Dong W, Jiang M. Current status and perspectives on biobutanol production using lignocellulosic feedstocks. Bioresour Technol Rep. 2019;7:100245.

113. Perret S, Casalot L, Fierobe HP, Tardif C, Sabathe F, Belaich JP, Belaich A. Production of heterologous and chimeric scaffoldins by Clostridium acetobutylicum ATCC 824. J Bacteriol. 2004;186(1):253-7.

114. Mazzoli R, Lamberti C, Pessione E. Engineering new metabolic capabilities in bacteria: lessons from recombinant cellulolytic strategies. Trends Biotechnol. 2012;30(2):111-9.

115. Amiri H, Karimi K. Pretreatment and hydrolysis of lignocellulosic wastes for butanol production: challenges and perspectives. Bioresour Technol. 2018:270:702-21.

116. Xiao M, Wang L, Wu Y, Cheng C, Chen L, Chen H, Xue C. Hybrid dilute sulfuric acid and aqueous ammonia pretreatment for improving butanol production from corn stover with reduced wastewater generation. Biores Technol. 2019;278:460-3.

117. Tashiro Y, Yoshida T, Noguchi T, Sonomoto K. Recent advances and future prospects for increased butanol production by acetone-butanolethanol fermentation. Eng Life Sci. 2013;13(5):432-45.

118. Qureshi N, Blaschek HP. Economics of butanol fermentation using hyper-butanol producing Clostridium beijerinckii BA101. Food Bioprod Process. 2000;78(C3):139-44.

119. Xiao H, Gu Y, Ning Y, Yang Y, Mitchell WJ, Jiang W, Yang S. Confirmation and elimination of xylose metabolism bottlenecks in glucose phosphoenolpyruvate-dependent phosphotransferase system-deficient Clostridium acetobutylicum for simultaneous utilization of glucose, xylose, and arabinose. Appl Environ Microbiol. 2011;77(22):7886-95.

120. Xiao H, Li Z, Jiang Y, Yang Y, Jiang W, Gu Y, Yang S. Metabolic engineering of D-xylose pathway in Clostridium beijerinckii to optimize solvent production from xylose mother liquid. Metab Eng. 2012;14(5):569-78.

121. Yu L, Xu M, Tang IC, Yang S-T. Metabolic engineering of Clostridium tyrobutyricum for n-butanol production through co-utilization of glucose and xylose. Biotechnol Bioeng. 2015;112(10):2134-41.

122. Guo T, He A-y, Du T-f, Zhu D-w, Liang D-f, Jiang M, Wei P, Ouyang P-k. Butanol production from hemicellulosic hydrolysate of corn fiber by a Clostridium beijerinckii mutant with high inhibitor-tolerance. Biores Technol. 2013;135:379-85.

123. GuY, Jiang $Y$, Yang S, Jiang W. Utilization of economical substratederived carbohydrates by solventogenic clostridia: pathway dissection, regulation and engineering. Curr Opin Biotechnol. 2014;29:124-31.

124. Pang Z-W, Lu W, Zhang H, Liang Z-W, Liang J-J, Du L-W, Duan C-J, Feng J-X. Butanol production employing fed-batch fermentation by Clostridium acetobutylicum GX01 using alkali-pretreated sugarcane bagasse hydrolysed by enzymes from Thermoascus aurantiacus QS 7-2-4. Biores Technol. 2016;212:82-91.

125. Qin Z, Duns GJ, Pan T, Xin F. Consolidated processing of biobutanol production from food wastes by solventogenic Clostridium sp. strain HN4. Bioresour Technol. 2018;264:148-53.

126. Xin F, Chen T, Jiang Y, Dong W, Zhang W, Zhang M, Wu H, Ma J, Jiang M. Strategies for improved isopropanol-butanol production by a Clostridium strain from glucose and hemicellulose through consolidated bioprocessing. Biotechnol Biofuels. 2017;10(1):118.

127. Jiang Y, Guo D, Lu J, Dürre P, Dong W, Yan W, Zhang W, Ma J, Jiang M, Xin F. Consolidated bioprocessing of butanol production from xylan by a thermophilic and butanologenic Thermoanaerobacterium sp M5. Biotechnol Biofuels. 2018;11(1):89.

128. Salehi Jouzani G, Taherzadeh MJ. Advances in consolidated bioprocessing systems for bioethanol and butanol production from biomass: a comprehensive review. Biofuel Res J. 2015;2(1):152-95.

129. Xin F, Dong W, Zhang W, Ma J, Jiang M. Biobutanol production from crystalline cellulose through consolidated bioprocessing. Trends Biotechnol. 2019:37(2):167-80.

130. Cheng H-H, Whang L-M, Chan K-C, Chung M-C, Wu S-H, Liu C-P, Tien S-Y, Chen S-Y, Chang J-S, Lee W-J. Biological butanol production from microalgae-based biodiesel residues by Clostridium acetobutylicum. Biores Technol. 2015;184:379-85.

131. Bengelsdorf FR, Straub M, Dürre P. Bacterial synthesis gas (syngas) fermentation. Environ Technol. 2013:34(13-14):1639-51.

132. Hou X, From N, Angelidaki I, Huijgen WJJ, Bjerre A-B. Butanol fermentation of the brown seaweed Laminaria digitata by Clostridium beijerinckii DSM-6422. Biores Technol. 2017;238:16-21. 
133. Cheng C, Li W, Lin M, Yang S-T. Metabolic engineering of Clostridium carboxidivorans for enhanced ethanol and butanol production from syngas and glucose. Biores Technol. 2019;284:415-23.

134. Rentmeister A. Current developments in cellulase engineering. Chem Ing Tec. 2013;85(6):818-25.

135. Thomas L, Joseph A, Gottumukkala LD. Xylanase and cellulase systems of Clostridium sp.: an insight on molecular approaches for strain improvement. Bioresour Technol. 2014;158:343-50.

136. Mann MS, Luetke-Eversloh T. Thiolase engineering for enhanced butanol production in Clostridium acetobutylicum. Biotechnol Bioeng. 2013;110(3):887-97.

137. Wen Z, Ledesma-Amaro R, Lin J, Jiang Y, Yang S. Improved n-butanol production from Clostridium cellulovorans by integrated metabolic and evolutionary engineering. Appl Environ Microbiol. 2019;85(7):e02560-18

138. Ezeji TC, Qureshi N, Blaschek HP. Acetone butanol ethanol (ABE) production from concentrated substrate: reduction in substrate inhibition by fed-batch technique and product inhibition by gas stripping. Appl Microbiol Biotechnol. 2004;63(6):653-8.

139. Xue C, Zhao X-Q, Liu C-G, Chen L-J, Bai F-W. Prospective and development of butanol as an advanced biofuel. Biotechnol Adv. 2013;31(8):1575-84

140. Maddox IS, Steiner E, Hirsch S, Wessner S, Gutierrez NA, Gapes JR, Schuster KC. The cause of "acid crash" and "acidogenic fermentations" duping the batch acetone-butanol-ethanol (ABE-) fermentation process. J Mol Microbiol Biotechnol. 2000;2(1):95-100

141. Desai RP, Harris LM, Welker NE, Papoutsakis ET. Metabolic flux analysis elucidates the importance of the acid-formation pathways in regulating solvent production by Clostridium acetobutylicum. Metab Eng. 1999;1(3):206-13

142. Choi SJ, Lee J, Jang Y-S, Park JH, Lee SY, Kim IH. Effects of nutritional enrichment on the production of acetone-butanol-ethanol (ABE) by Clostridium acetobutylicum. J Microbiol. 2012;50(6):1063-6.

143. Woo JE, Lee SY, Jang Y-S. Effects of nutritional enrichment on acid production from degenerated (non-solventogenic) Clostridium acetobutylicum strain M5. Appl Biol Chem. 2018:61(4):469-72.

144. Borden JR, Jones SW, Indurthi D, Chen Y, Papoutsakis ET. A genomiclibrary based discovery of a novel, possibly synthetic, acid-tolerance mechanism in Clostridium acetobutylicum involving non-coding RNAs and ribosomal RNA processing. Metab Eng. 2010;12(3):268-81.

145. Baral NR, Li JZ, Jha AK. Perspective and prospective of pretreatment of corn straw for butanol production. Appl Biochem Biotechnol. 2014;172(2):840-6.

146. Ezeji TC, Qureshi N, Blaschek HP. Bioproduction of butanol from biomass: from genes to bioreactors. Curr Opin Biotechnol. 2007; 18(3):220-7.

147. Mussatto SI, Roberto IC. Alternatives for detoxification of diluted-acid lignocellulosic hydrolyzates for use in fermentative processes: a review. Biores Technol. 2004:93(1):1-10.

148. Patakova P, Linhova M, Rychtera M, Paulova L, Melzoch K. Novel and neglected issues of acetone-butanol-ethanol (ABE) fermentation by clostridia: Clostridium metabolic diversity, tools for process mapping and continuous fermentation systems. Biotechnol Adv. 2013;31(1):58-67.

149. Borden JR, Papoutsakis ET. Dynamics of genomic-library enrichment and identification of solvent tolerance genes for Clostridium acetobutylicum. Appl Environ Microbiol. 2007:73(9):3061-8.

150. Lepage C, Fayolle F, Hermann M, Vandecasteele JP. Changes in membrane lipid composition of Clostridium acetobutylicum during acetone butanol fermentation: effects of solvents, growth temperature and $\mathrm{pH}$. Microbiology. 1987;133(1):103-10

151. Guo J, Ho JC, Chin H, Mark AE, Zhou C, Kjelleberg S, Liedberg B, Parikh AN, Cho N-J, Hinks J. Response of microbial membranes to butanol: interdigitation vs. disorder. Phys Chem Chem Phys. 2019;21(22):11903-15.

152. Alsaker KV, Paredes C, Papoutsakis ET. Metabolite stress and tolerance in the production of biofuels and chemicals: gene-expression-based systems analysis of butanol, butyrate, and acetate stresses in the anaerobe Clostridium acetobutylicum. Biotechnol Bioeng. 2010;105(6):1131-47.
153. Ezeji TC, Qureshi N, Blaschek HP. Butanol fermentation research: upstream and downstream manipulations. Chem Rec. 2004:4(5):305-14

154. Xue C, Zhao J, Lu C, Yang S-T, Bai F, Tang IC. High-titer n-butanol production by Clostridium acetobutylicum JB200 in fed-batch fermentation with intermittent gas stripping. Biotechnol Bioeng. 2012;109(11):2746-56

155. Sheng Y, Wu J, Zhao L, Wu C, Qi Z, Cao G. Optimization of culture conditions for enhanced butanol production by a high butanol tolerant Clostridium Beijerinckii F-6. Energy Procedia. 2019;158:471-6.

156. García V, Päkkilä J, Ojamo H, Muurinen E, Keiski RL. Challenges in biobutanol production: how to improve the efficiency? Renew Sustain Energy Rev. 2011;15(2):964-80.

157. Janssen $\mathrm{H}$, Grimmler C, Ehrenreich A, Bahl H, Fischer R-J. A transcriptional study of acidogenic chemostat cells of Clostridium acetobutylicum-solvent stress caused by a transient n-butanol pulse. J Biotechnol. 2012;161(3):354-65

158. Nicolaou SA, Gaida SM, Papoutsakis ET. A comparative view of metabolite and substrate stress and tolerance in microbial bioprocessing: from biofuels and chemicals, to biocatalysis and bioremediation. Metab Eng. 2010;12(4):307-31.

159. Patakova P, Kolek J, Sedlar K, Koscova P, Branska B, Kupkova K, Paulova $L$, Provaznik I. Comparative analysis of high butanol tolerance and production in clostridia. Biotechnol Adv. 2018;36(3):721-38.

160. Patnaik R, Louie S, Gavrilovic V, Perry K, Stemmer WP, Ryan CM, del Cardayré S. Genome shuffling of Lactobacillus for improved acid tolerance. Nat Biotechnol. 2002;20(7):707.

161. Mao S, Luo Y, Bao G, Zhang Y, Li Y, Ma Y. Comparative analysis on the membrane proteome of Clostridium acetobutylicum wild type strain and its butanol-tolerant mutant. Mol BioSyst. 2011;7(5):1660-77.

162. Hou X, Peng W, Xiong L, Huang C, Chen X, Chen X, Zhang W. Engineering Clostridium acetobutylicum for alcohol production. J Biotechnol. 2013;166(1-2):25-33.

163. Xu M, Zhao J, Yu L, Yang S-T. Comparative genomic analysis of Clostridium acetobutylicum for understanding the mutations contributing to enhanced butanol tolerance and production. J Biotechnol. 2017;263:36-44.

164. Tian L, Cervenka ND, Low AM, Olson DG, Lynd LR. A mutation in the AdhE alcohol dehydrogenase of Clostridium thermocellum increases tolerance to several primary alcohols, including isobutanol, n-butanol and ethanol. Sci Rep. 2019;9(1):1736.

165. Liao Z, Zhang Y, Luo S, Suo Y, Zhang S, Wang J. Improving cellular robustness and butanol titers of Clostridium acetobutylicum ATCC824 by introducing heat shock proteins from an extremophilic bacterium. J Biotechnol. 2017;252:1-10.

166. Tomas CA, Beamish J, Papoutsakis ET. Transcriptional analysis of butanol stress and tolerance in Clostridium acetobutylicum. J Bacteriol. 2004;186(7):2006-18.

167. Mann MS, Dragovic Z, Schirrmacher G, Luetke-Eversloh T. Overexpression of stress protein-encoding genes helps Clostridium acetobutylicum to rapidly adapt to butanol stress. Biotech Lett. 2012;34(9):1643-9.

168. Jia K, Zhang Y, Li Y. Identification and characterization of two functionally unknown genes involved in butanol tolerance of Clostridium acetobutylicum. PLoS ONE. 2012;7(6):e38815.

169. Nimbalkar PR, Khedkar MA, Kulkarni RK, Chavan PV, Bankar SB. Strategic intensification in butanol production by exogenous amino acid supplementation: fermentation kinetics and thermodynamic studies. Biores Technol. 2019;288:121521.

170. Oshiro M, Hanada K, Tashiro Y, Sonomoto K. Efficient conversion of lactic acid to butanol with $\mathrm{pH}$-stat continuous lactic acid and glucose feeding method by Clostridium saccharoperbutylacetonicum. Appl Microbio Biotechnol. 2010;87(3):1177-85

171. Al-Shorgani NKN, Ali E, Kalil MS, Yusoff WMW. Bioconversion of butyric acid to butanol by Clostridium saccharoperbutylacetonicum N1-4 (ATCC 13564) in a limited nutrient medium. Bioenergy Res. 2012;5(2):287-93.

172. Al-Shorgani NKN, Shukor H, Abdeshahian P, Kalil MS, YusoffWMW, Hamid AA. Enhanced butanol production by optimization of medium parameters using Clostridium acetobutylicum YM1. Saudi J Biol Sci. 2018;25(7):1308-21 
173. Al-Shorgani NKN, Kalil MS, Yusoff WMW, Hamid AA. Impact of pH and butyric acid on butanol production during batch fermentation using a new local isolate of Clostridium acetobutylicum YM1. Saudi J Biol Sci. 2018;25(2):339-48.

174. GuY, Hu S, Chen J, Shao L, He H, Yang Y, Yang S, Jiang W. Ammonium acetate enhances solvent production by Clostridium acetobutylicum EA 2018 using cassava as a fermentation medium. J Ind Microbiol Biotechnol. 2009;36(9):1225-32.

175. Singh K, Gedam PS, Raut AN, Dhamole PB, Dhakephalkar PK, Ranade DR. Enhanced n-butanol production by Clostridium beijerinckii MCMB 581 in presence of selected surfactant. 3 Biotech. 2017;7:161.

176. Mukherjee M, Sarkar P, Goswami G, Das D. Regulation of butanol biosynthesis in Clostridium acetobutylicum ATCC 824 under the influence of zinc supplementation and magnesium starvation. Enzym Microb Technol. 2019;129:109352.

177. Jiang Y, Zhang T, Lu J, Dürre P, Zhang W, Dong W, Zhou J, Jiang M, Xin F. Microbial co-culturing systems: butanol production from organic wastes through consolidated bioprocessing. Appl Microbiol Biotechnol. 2018;102(13):5419-25

178. Wu J, Dong L, Zhou C, Liu B, Feng L, Wu C, Qi Z, Cao G. Developing a coculture for enhanced butanol production by Clostridium beijerinckii and Saccharomyces cerevisiae. Bioresour Technol Rep. 2019:6:223-8.

179. Luo HZ, Zeng QW, Han S, Wang ZY, Dong Q, Bi YH, Zhao YP. High-efficient n-butanol production by co-culturing Clostridium acetobutylicum and Saccharomyces cerevisiae integrated with butyrate fermentative supernatant addition. World J Microbiol Biotechnol. 2017;33(4):76.

180. Hu M, Wu Z, Sun L, Guo S, Li H, Liao J, Huang C, Wang B. Improving pervaporation performance of PDMS membranes by interpenetrating polymer network for recovery of bio-butanol. Sep Purif Technol. 2019;228:115690.

181. Nakayama S, Kiyoshi K, Kadokura T, Nakazato A. Butanol production from crystalline cellulose by cocultured Clostridium thermocellum and Clostridium saccharoperbutylacetonicum N1-4. Appl Environ Microbiol. 2011;77(18):6470-5

182. Abd-Alla MH, El-Enany AWE. Production of acetone-butanol-ethanol from spoilage date palm (Phoenix dactylifera L.) fruits by mixed culture of Clostridium acetobutylicum and Bacillus subtilis. Biomass Bioenergy. 2012:42:172-8

183. Honicke D, Janssen H, Grimmler C, Ehrenreich A, Lutke-Eversloh T. Global transcriptional changes of Clostridium acetobutylicum cultures with increased butanol:acetone ratios. N Biotechnol. 2012;29(4):485-93.

184. Chen $L$, Wu YD, Xue C, Bai FW. Improving fructose utilization and butanol production by Clostridium acetobutylicum via extracellular redox potential regulation and intracellular metabolite analysis. Biotechnol J. 2017. https://doi.org/10.1002/biot.201700198.

185. Nakayama S-i, Kosaka T, Hirakawa H, Matsuura K, Yoshino S, Furukawa K. Metabolic engineering for solvent productivity by downregulation of the hydrogenase gene cluster hupCBA in Clostridium saccharoperbutylacetonicum strain N1-4. Appl Microbiol Biotechnol. 2008;78(3):483-93.

186. Wietzke $M, B a h l H$. The redox-sensing protein Rex, a transcriptional regulator of solventogenesis in Clostridium acetobutylicum. Appl Microbiol Biotechnol. 2012;96(3):749-61.

187. Yang Y, Yong Hong W, Ju C, YingPing Z, SiLiang Z. The influence of controlling redox potential on ethanol production by Saccharomyces cerevisiae. Chin J Biotechnol. 2007;23(5):878-84.

188. Ding J, Luo H, Xie F, Wang H, Xu M, Shi Z. Electron receptor addition enhances butanol synthesis in ABE fermentation by Clostridium acetobutylicum. Biores Technol. 2018;247:1201-5.

189. Kim DH, Han SK, Kim SH, Shin HS. Effect of gas sparging on continuous fermentative hydrogen production. Int J Hydrogen Energy. 2006;31(15):2158-69.

190. Wang SH, Zhu Y, Zhang YP, Li Y. Controlling the oxidoreduction potential of the culture of Clostridium acetobutylicum leads to an earlier initiation of solventogenesis, thus increasing solvent productivity. Appl Microbiol Biotechnol. 2012;93(3):1021-30.

191. Xue C, Cheng C. Butanol production by Clostridium. Adv Bioenergy. 2019:4:35.

192. Carter GP, Purdy D, Williams P, Minton NP. Quorum sensing in Clostridium difficile: analysis of a luxS-type signalling system. J Med Microbiol. 2005;54(2):119-27.
193. Ohtani K, Hayashi H, Shimizu T. The luxS gene is involved in cell-cell signalling for toxin production in Clostridium perfringens. Mol Microbiol. 2002:44(1):171-9.

194. Ezeji T, Qureshi N, Blaschek HP. Production of acetone-butanol-ethanol $(\mathrm{ABE})$ in a continuous flow bioreactor using degermed corn and Clostridium beijerinckii. Process Biochem. 2007;42(1):34-9.

195. Jang YS, Malaviya A, Lee SY. Acetone-butanol-ethanol production with high productivity using Clostridium acetobutylicum BKM19. Biotechnol Bioeng. 2013;110(6):1646-53.

196. Bankar SB, Survase SA, Ojamo H, Granström T. Biobutanol: the outlook of an academic and industrialist. RSC Adv. 2013;3(47):24734-57.

197. Khalifaa KK, Al-Tabiba Al, Kalila MS, Al-Shorgania NKN. High yield of butanol production in repeated batch culture fermentation by Clostridium Acetobutylicum YM1. Jurnal Kejuruteraan. 2018;1(4):7-14

198. Liu D, Chen Y, Ding FY, Zhao T, Wu JL, Guo T, Ren HF, Li BB, Niu HQ, Cao $Z$, et al. Biobutanol production in a Clostridium acetobutylicum biofilm reactor integrated with simultaneous product recovery by adsorption. Biotechnol Biofuels. 2014;7:5.

199. Marina N, Bayon JC, Maria ELD, Gutierrez A, Inchausti M, Bustamante V, Galdiz JB. Economic assessment and budgetary impact of a telemedicine procedure and spirometry quality control in the primary care setting. Arch Bronconeumol. 2016;52(1):24-8.

200. Staggs KW, Nielsen DR. Improving n-butanol production in batch and semi-continuous processes through integrated product recovery. Process Biochem. 2015;50(10):1487-98.

201. Wiehn M, Staggs K, Wang YC, Nielsen DR. In situ butanol recovery from Clostridium acetobutylicum fermentations by expanded bed adsorption. Biotechnol Prog. 2014;30(1):68-78.

202. Xue C, Zhao JB, Chen LJ, Bai FW, Yang ST, Sun JX. Integrated butano recovery for an advanced biofuel: current state and prospects. Appl Microbiol Biotechnol. 2014:98(8):3463-74.

203. Lee SY, Park JH, Jang SH, Nielsen LK, Kim J, Jung KS. Fermentative butanol production by Clostridia. Biotechnol Bioeng. 2008;101(2):209-28.

204. Cai D, Hu S, Miao Q, Chen CJ, Chen HD, Zhang CW, Li P, Qin PY, Tan TW. Two-stage pervaporation process for effective in situ removal acetone-butanol-ethanol from fermentation broth. Biores Technol. 2017:224:380-8.

205. Zheng P-Y, Li X-Q, Wu J-K, Wang N-X, Li J, An Q-F. Enhanced butanol selectivity of pervaporation membrane with fluorinated monolayer on polydimethylsiloxane surface. J Membr Sci. 2018;548:215-22.

206. Lee JY, Hwang SO, Kim H-J, Hong D-Y, Lee JS, Lee J-H. Hydrosilylationbased UV-curable polydimethylsiloxane pervaporation membranes for n-butanol recovery. Sep Purif Technol. 2019;209:383-91.

207. Tang W, Lou H, Li Y, Kong X, Wu Y, Gu X. Ionic liquid modified graphene oxide-PEBA mixed matrix membrane for pervaporation of butanol aqueous solutions. J Membr Sci. 2019;581:93-104.

208. Zhang G, Cheng H, Su P, Zhang X, Zheng J, Lu Y, Liu Q. PIM-1/PDMS hybrid pervaporation membrane for high-efficiency separation of n-butanol-water mixture under low concentration. Sep Purif Technol. 2019:216:83-91.

209. Lee S-H, Yun EJ, Kim J, Lee SJ, Um Y, Kim KH. Biomass, strain engineering, and fermentation processes for butanol production by solventogenic clostridia. Appl Environ Microbiol. 2016;100(19):8255-71.

210. dos Santos Vieira CF, Maugeri Filho F, Maciel Filho R, Mariano AP. Acetone-free biobutanol production: past and recent advances in the isopropanol-butanol-ethanol (IBE) fermentation. Bioresour Technol. 2019:287:121425

211. Lee J, Jang Y-S, Choi SJ, Im JA, Song H, Cho JH, Seung DY, Papoutsakis ET, Bennett GN, Lee SY. Metabolic engineering of Clostridium acetobutylicum ATCC 824 for isopropanol-butanol-ethanol fermentation. Appl Environ Microbiol. 2012;78(5):1416-23.

212. Jang Y-S, Malaviya A, Lee J, Im JA, Lee SY, Lee J, Eom M-H, Cho J-H, Seung DY. Metabolic engineering of Clostridium acetobutylicum for the enhanced production of isopropanol-butanol-ethanol fuel mixture. Biotechnol Prog. 2013;29(4):1083-8.

213. Dwidar M, Park J-Y, Mitchell RJ, Sang B-I. The future of butyric acid in industry. Sci World J. 2012;20(12):417-71.

214. Canganella F, Wiegel J. Continuous cultivation of Clostridium thermobutyricum in a rotary fermentor system. J Ind Microbiol Biotechnol. 2000:24(1):7-13. 
215. Cho C, Jang YS, Moon HG, Lee J, Lee SY. Metabolic engineering of clostridia for the production of chemicals. Biofuels Bioprod Biorefin. 2015;9(2):211-25.

216. Xin F, Dong W, Jiang Y, Ma J, Zhang W, Wu H, Zhang M, Jiang M. Recent advances on conversion and co-production of acetone-butanolethanol into high value-added bioproducts. Crit Rev Biotechnol. 2018;38(4):529-40.

217. Li S, Zhou Y, Luo Z, Cui Y, Xu Y, Lin L, Zhao M, Guo Y, Pang Z. Dual function of ammonium acetate in acetone-butanol-ethanol fermentation by Clostridium acetobutylicum. Biores Technol. 2018;267:319-25.

218. Marcheschi RJ, Gronenberg LS, Liao JC. Protein engineering for metabolic engineering: current and next-generation tools. Biotechnol J. 2013;8(5):545-55.

219. Brunette TJ, Parmeggiani F, Huang P-S, Bhabha G, Ekiert DC, Tsutakawa SE, Hura GL, Tainer JA, Baker D. Exploring the repeat protein universe through computational protein design. Nature. 2015;528(7583):580-9.

220. Liao C, Seo S-O, Lu T. System-level modeling of acetone-butanol-ethanol fermentation. FEMS Microbiol Lett. 2016;363(9):fnw074.

221. Abdehagh N, Tezel FH, Thibault J. Separation techniques in butanol production: challenges and developments. Biomass Bioenerg. 2014;60:222-46.

222. Jang Y-S, Park JM, Choi S, Choi YJ, Seung DY, Cho JH, Lee SY. Engineering of microorganisms for the production of biofuels and perspectives based on systems metabolic engineering approaches. Biotechnol Adv. 2012;30(5):989-1000.

223. Lu C, Yu L, Varghese S, Yu M, Yang S-T. Enhanced robustness in acetonebutanol-ethanol fermentation with engineered Clostridium beijerinckii overexpressing adhE2 and ctfAB. Biores Technol. 2017;243:1000-8.

224. Shao L, Hu S, Yang Y, Gu Y, Chen J, Yang Y, Jiang W, Yang S. Targeted gene disruption by use of a group II intron (targetron) vector in Clostridium acetobutylicum. Cell Res. 2007:17(11):963-5.

225. Heap JT, Pennington OJ, Cartman ST, Minton NP. A modular system for Clostridium shuttle plasmids. J Microbiol Methods. 2009;78(1):79-85.

226. Feustel L, Nakotte S, Durre P. Characterization and development of two reporter gene systems for Clostridium acetobutylicum. Appl Environ Microbiol. 2004;70(2):798-803.

227. Mermelstein LD, Papoutsakis ET. In vivo methylation in Escherichia coli by the Bacillus subtilis phage phi 3T I methyltransferase to protect plasmids from restriction upon transformation of Clostridium acetobutylicum ATCC 824. Appl Environ Microbiol. 1993;59(4):1077-81.

228. Tummala SB, Welker NE, Papoutsakis ET. Development and characterization of a gene expression reporter system for Clostridium acetobutylicum ATCC 824. Appl Environ Microbiol. 1999;65(9):3793-9.

229. Heap JT, Ehsaan M, Cooksley CM, Ng Y-K, Cartman ST, Winzer K, Minton NP. Integration of DNA into bacterial chromosomes from plasmids without a counter-selection marker. Nucleic Acids Res. 2012:40(8):e59.

230. Kovács K, Willson BJ, Schwarz K, Heap JT, Jackson A, Bolam DN, Winzer K, Minton NP. Secretion and assembly of functional mini-cellulosomes from synthetic chromosomal operons in Clostridium acetobutylicum ATCC 824. Biotechnol Biofuels. 2013;6(1):117.

231. Lee J, Jang Y-S, Papoutsakis ET, Lee SY. Stable and enhanced gene expression in Clostridium acetobutylicum using synthetic untranslated regions with a stem-loop. J Biotechnol. 2016;230:40-3.

232. Nair RV, Green EM, Watson DE, Bennett GN, Papoutsakis ET. Regulation of the sol locus genes for butanol and acetone formation in Clostridium acetobutylicum ATCC 824 by a putative transcriptional repressor. J Bacteriol. 1999;181(1):319-30.

233. Harris LM, Welker NE, Papoutsakis ET. Northern, morphological, and fermentation analysis of spo0A inactivation and overexpression in Clostridium acetobutylicum ATCC 824. J Bacteriol. 2002;184(13):3586-97.

234. Scotcher MC, Bennett GN. SpollE regulates sporulation but does not directly affect solventogenesis in Clostridium acetobutylicum ATCC 824 J Bacteriol. 2005;187(6):1930-8.

235. Jia K, Zhu Y, Zhang Y, Li Y. Group II intron-anchored gene deletion in Clostridium. PLOS ONE. 2011;6(1):e16693.

236. Wang Y, Li X, Milne CB, Janssen H, Lin W, Phan G, Hu H, Jin Y-S, Price ND, Blaschek HP. Development of a gene knockout system using mobile Group II Introns (Targetron) and genetic disruption of acid production pathways in Clostridium beijerinckii. Appl Environ Microbiol. 2013;79(19):5853-63.

237. Al-Hinai MA, Fast AG, Papoutsakis ET. Novel system for efficient isolation of Clostridium double-crossover allelic exchange mutants enabling markerless chromosomal gene deletions and DNA integration. Appl Environ Microbiol. 2012;78(22):8112-21.

238. Harris LM, Desai RP, Welker NE, Papoutsakis ET. Characterization of recombinant strains of the Clostridium acetobutylicum butyrate kinase inactivation mutant: need for new phenomenological models for solventogenesis and butanol inhibition? Biotechnol Bioeng. 2000;67(1):1-11.

239. Qureshi N, Saha BC, Dien B, Hector RE, Cotta MA. Production of butanol (a biofuel) from agricultural residues: part L-use of barley straw hydrolysate. Biomass Bioenerg. 2010;34(4):559-65.

240. Qureshi N, Sahaa BC, Hector RE, Hughes SR, Cotta MA. Butanol production from wheat straw by simultaneous saccharification and fermentation using Clostridium beijerinckii: part I-batch fermentation. Biomass Bioenerg. 2008;32(2):168-75.

241. Tashiro Y, Takeda K, Kobayashi G, Sonomoto K, Ishizaki A, Yoshino S. High butanol production by Clostridium saccharoperbutylacetonicum N1-4 in fed-batch culture with pH-stat continuous butyric acid and glucose feeding method. J Biosci Bioeng. 2004;98(4):263-8.

242. Liew ST, Arbakariya A, Rosfarizan M, Raha AR. Production of solvent (acetone-butanol-ethanol) in continuous fermentation by Clostridium saccharobutylicum DSM 13864 using gelatinised sago starch as a carbon source. Malays J Microbiol. 2006;2(2):42-50.

243. Huang WC, Ramey DE, Yang ST. Continuous production of butanol by Clostridium acetobutylicum immobilized in a fibrous bed bioreactor. Appl Biochem Biotechnol. 2004;113:887-98.

244. Qureshi N, Lai LL, Blaschek HP. Scale-up of a high productivity continuous biofilm reactor to produce butanol by adsorbed cells of Clostridium beuerinckii. Food Bioprod Process. 2004;82(2):164-73.

245. Tashiro Y, Takeda K, Kobayashi G, Sonomoto K. High production of acetone-butanol-ethanol with high cell density culture by cell-recycling and bleeding. J Biotechnol. 2005;120(2):197-206.

246. Xue C, Liu F, Xu M, Tang I-C, Zhao J, Bai F, Yang S-T. Butanol production in acetone-butanol-ethanol fermentation with in situ product recovery by adsorption. Biores Technol. 2016;219:158-68.

247. Li J, Chen X, Qi B, Luo J, Zhang Y, Su Y, Wan Y. Efficient production of acetone-butanol-ethanol (ABE) from cassava by a fermentation-pervaporation coupled process. Biores Technol. 2014;169:251-7.

248. Lu C, Zhao J, Yang S-T, Wei D. Fed-batch fermentation for n-butanol production from cassava bagasse hydrolysate in a fibrous bed bioreactor with continuous gas stripping. Biores Technol. 2012;104:380-7.

249. Ezeji TC, Qureshi N, Blaschek HP. Production of acetone, butanol and ethanol by Clostridium beijerinckii BA101 and in situ recovery by gas stripping. World J Microbiol Biotechnol. 2003;19(6):595-603.

250. Dhamole PB, Wang Z, Liu Y, Wang B, Feng H. Extractive fermentation with non-ionic surfactants to enhance butanol production. Biomass Bioenergy. 2012;40:112-9.

251. Oudshoorn A, van der Wielen LAM, Straathof AJJ. Assessment of options for selective 1-butanol recovery from aqueous solution. Ind Eng Chem Res. 2009;48(15):7325-36.

252. Eom MH, Kim W, Lee J, Cho JH, Seung D, Park S, Lee JH. Modeling of a biobutanol adsorption process for designing an extractive fermentor. Ind Eng Chem Res. 2013;52(2):603-11.

253. Tanaka S, Tashiro Y, Kobayashi G, Ikegami T, Negishi H, Sakaki K. Membrane-assisted extractive butanol fermentation by Clostridium saccharoperbutylacetonicum N1-4 with 1-dodecanol as the extractant. Biores Technol. 2012;116:448-52.

\section{Publisher's Note}

Springer Nature remains neutral with regard to jurisdictional claims in published maps and institutional affiliations. 